\title{
The Geo-Hydro-Mechanical Properties of a Turbiditic Formation as Internal Factors of Slope Failure Processes
}

\author{
Nunzio Losacco ${ }^{1, *}$, Osvaldo Bottiglieri ${ }^{1}$, Francesca Santaloia ${ }^{2}$, Claudia Vitone ${ }^{1}$ (D) and Federica Cotecchia ${ }^{1}$ (I) \\ 1 DICATECH, Politecnico di Bari, Via Edoardo Orabona 4, 70125 Bari, Italy; osvaldo.bottiglieri@poliba.it (O.B.); \\ claudia.vitone@poliba.it (C.V.); federica.cotecchia@poliba.it (F.C.) \\ 2 IRPI, National Research Council, Via Giovanni Amendola 122, 70126 Bari, Italy; f.santaloia@ba.irpi.cnr.it \\ * Correspondence: nunzio.losacco@poliba.it; Tel.: +39-0805963363
}

check for

updates

Citation: Losacco, N.; Bottiglieri, O.; Santaloia, F.; Vitone, C.; Cotecchia, F.

The Geo-Hydro-Mechanical

Properties of a Turbiditic Formation

as Internal Factors of Slope Failure

Processes. Geosciences 2021, 11, 429.

https://doi.org/10.3390/

geosciences 11100429

Academic Editors: Sadik Khan,

Asif Ahmed and Jesus Martinez-Frias

Received: 5 August 2021

Accepted: 14 October 2021

Published: 17 October 2021

Publisher's Note: MDPI stays neutral with regard to jurisdictional claims in published maps and institutional affiliations.

Copyright: (c) 2021 by the authors. Licensee MDPI, Basel, Switzerland. This article is an open access article distributed under the terms and conditions of the Creative Commons Attribution (CC BY) license (https:// creativecommons.org/licenses/by/ $4.0 /)$.

\begin{abstract}
Similar to many inner areas of Southern Europe, the Daunia Apennines are affected by widespread landsliding, often consisting of slow, deep-seated movements. Recurrent acceleration of these landslides causes damage to buildings and infrastructures, severely biasing the socio-economic development of the region. Most landslides in the area of study occur within clayey units of turbiditic flysch formations, often severely disturbed by tectonic thrust and previous landsliding. The Faeto Flysch (FAE) is one of the most widespread turbiditic formations in the Daunia Apennines and is representative of the tectonised geological formations involved in slope failure. This work, by examining the landslide processes occurring at four pilot sites, aims at connecting the observed mechanisms to the geo-hydro-mechanical setup of FAE in the slopes. It is found that the soil portion of FAE consists of highly plastic clays, resulting in low intrinsic shear strength, and hence controls the initiation and progression of failure in the slopes, as such representing an internal predisposing factor to landsliding. In addition, the presence of fractured rock strata confers a high permeability at the slope scale, with respect to that of the soil matrix. This results in severe piezometric levels in the slope, which represent another internal predisposing factor to failure, and in the ability to induce significant seasonal pore water pressure oscillations down to great depths, connected to rainfall infiltration, thus triggering the recurrent acceleration of the landslides.
\end{abstract}

Keywords: landslide mechanism; geo-hydro-mechanical setting; turbiditic flysch; geotechnical characterisation; high plasticity clay

\section{Introduction}

The eastern front of the Italian Southern Apennines, i.e., the Daunia Apennines, is a location of extensive slope failure processes. These consist mainly of medium depth to deep, slow to very slow-moving landslides (maximum depth of the shear band greater than $10 \mathrm{~m}$ b.g.l., average displacement rate less than 200 or $20 \mathrm{~mm} /$ year, respectively [1]), despite the gentle slope inclinations (typically around $10^{\circ}$ ) and the relatively short elevations (below $1000 \mathrm{~m}$ a.s.1.). In many cases, present-day slope movements are reactivations of pre-existing landslides, and evidence of their renewed activity is provided by the repeated occurrence of extensive damage of structures and infrastructures [2]. From time to time, the aforementioned phenomena accelerate as a result of the interplay between predisposing and triggering landslide factors [3].

Typically, the historic portions of the Daunia urban centres rise on hilltops, the location of the most stable rocky unit outcrops and are widely bordered by the rear scarps of landslide bodies. Hence, they are often spared from the slope activity, although lack of earth support of the foundation soils due to the retrogression of the rear scarps can, in some cases, harm the most peripheral buildings. Conversely, most of the landslide-induced damages affect buildings in suburbs of more recent urban expansion, as well as linear infrastructures in peri urban areas (e.g., roads, railways, aqueducts, pipelines), where the peculiar nature of the subsoil concurs to make the slopes prone to instability, as discussed 
in this paper. Consequently, the socioeconomic development of the inner areas of reference in this study is severely biased by the fragility of the territory. Therefore, characterising the predisposing factors to landsliding helps in building the resilience of these communities. It is worth pointing out that the latter, in the light of the ongoing global crisis, might play a key role in the compelling quest for a new model of sustainable development.

As discussed by [2], most of the landslides in the Daunia Apennines occur within clayey units that are part of flysch formations, of turbiditic origin, consisting of limestone and sandstone strata interbedded with clayey marls and clays, which often represent the matrix of the formation. These materials are heavily disturbed due to both tectonic thrusts, related to the intense orogenic activity of the region, and widespread ancient landsliding, as such, leaving the clayey layers severely sheared, and the rocky strata generally fractured and floating as disarranged rock masses in the soil matrix. Tectonised turbidites, due to their lithological variability, heterogeneous consistency and mesostructured features, are part of the so-called "structurally complex formations". Several research studies [4-13] have shown that the clayey part of these formations, which controls the stability of the slopes, exhibits very low shear strength, compared to that of soils of the same composition but possessing a structure that has not experienced severe disturbance. The poor mechanical properties, together with the high piezometric heads usually measured down to great depths in the slopes, represent common internal factors [3] predisposing the slopes to failure in the region [9,14-19].

The Faeto Flysch (FAE) is one of the most widespread turbiditic formations in the Daunia Apennines and can be thought of as representative of the tectonised geological formations involved in the slope failure processes recalled above. The FAE embodies syngeneic heterogeneities, as a result of the processes bringing about its formation. Therefore, it is characterised by a notable lithological and geo-structural diversity, in turn reflected into the variability of the geotechnical properties of the piled-up strata. Among such strata, the clayey ones are characterized by the poorest strength parameters and, as such, are almost always the locations of failure initiation processes. At the same time, the more or less abundant fractured rock layers alternating the clayey strata confer, to the slopes made of FAE, site-scale permeability values higher than those typical for clayey slopes $[14,20,21]$. Therefore, the piezometric levels in the slopes made of FAE are generally high and also represent landslide predisposing factors. Furthermore, the landslide activity is often found to be weather-driven, even for deep-seated landslides [22-24].

With reference to case histories of landslide mechanisms involving the FAE, this paper exemplifies how the geo-hydro-mechanical (GHM) properties of turbiditic formations may control landslide mechanisms, as recurrently observed in the southern Apennines, e.g., Pisciolo [9,14,25], Santa Croce di Magliano [8,9,26], Montaguto [27-30]; Brindisi di Montagna [31-33] landslides. In particular, the paper refers to the case histories of Motta Montecorvino, Volturino, Bovino and Biccari (Figure 1), discussing the similarities and differences among the landslide mechanisms at the sites and how they are related to the FAE geo-hydro-mechanical setups in the slopes. The Faeto Flysch is just one of the possible examples of several tectonised turbidites which share many common geo-hydro-mechanical features (e.g., heterogeneity, low shear strength of soil portion, litho-stratigraphic and geostructural arrangement, etc.), due to similarities in the main aspects of their geological history, since deposition. Hence, the results of this study are applicable to geostructural contexts similar to those of reference in this study, in other areas of the world. 


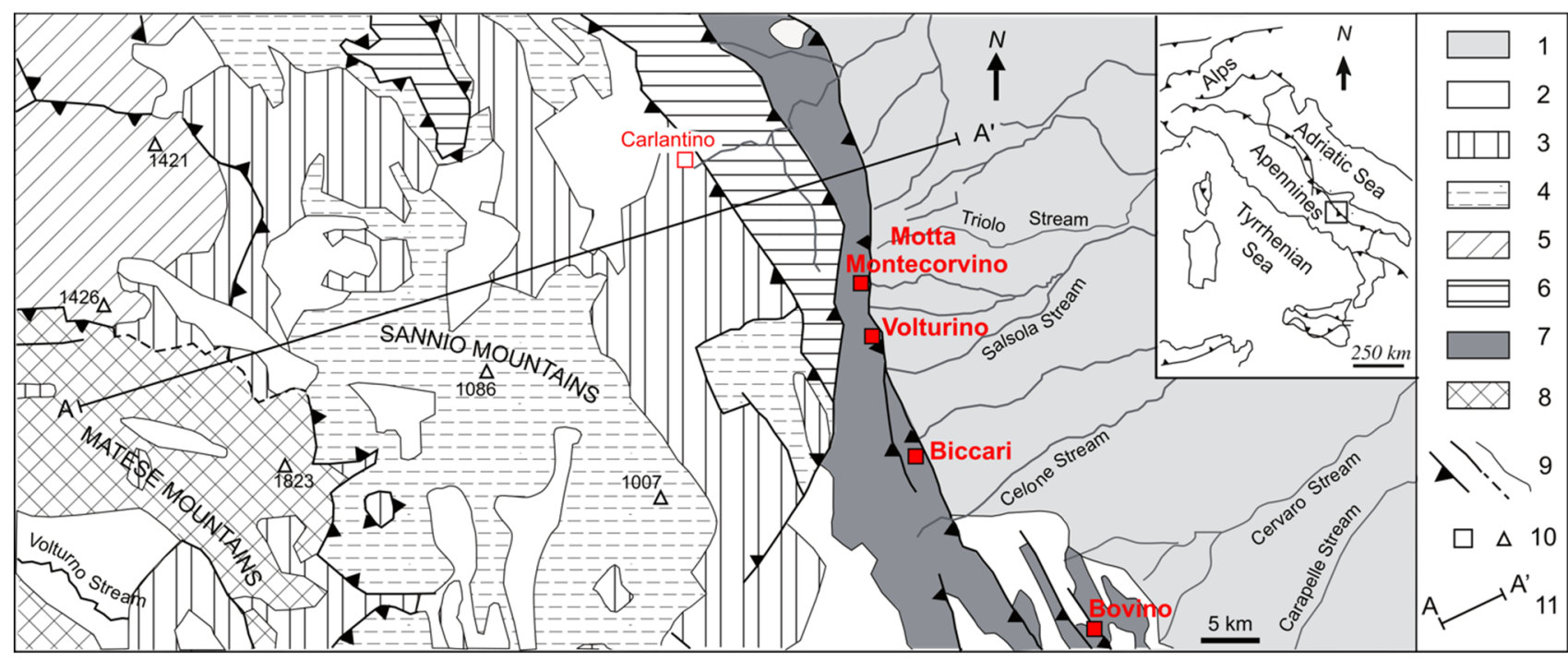

Figure 1. Simplified geological map of the Apennine sector showing examined sites (modified from [34]). Key: (1) continental and marine deposits (lower Pleistocene-Holocene), volcanite and volcanoclastic deposits (middle Pleistocene-Holocene); (2) Pliocene-Messinian deposits; (3) uppermost Tortonian-Messinian terrigeneous deposits unconformably overlying the Apenninic Units (San Bartolomeo Flysch, Toppo Capuana Marls, San Massimo Sandstone, Sant'Elena Sandstone); Apenninic Units: (4) Sannio Unit (lower Cretaceous-Serravallian; also locally included deposits belonging to Fortore Unit); (5) Frosolone-Agnone Unit (Jurassic-Messinian; also locally included deposits belonging to Fortore Unit); (6) Tufillo-Serra Palazzo Units (Paleogene-Messinian; also locally included deposits belonging to Fortore Unit); (7) Daunia Unit (PaleogeneMessinian); (8) Simbruini-Matese Units (Jurassic-Tortonian); (9) thrust (left), tectonic (middle, dashed when inferred) and stratigraphic (right) contact; (10) urban areas cited in the paper (left) and altitude points (right); (11) trace of cross-section $\mathrm{A}-\mathrm{A}^{\prime}$ (Figure 2). Schematic geostructural map of Italy in the top-right corner of the figure.

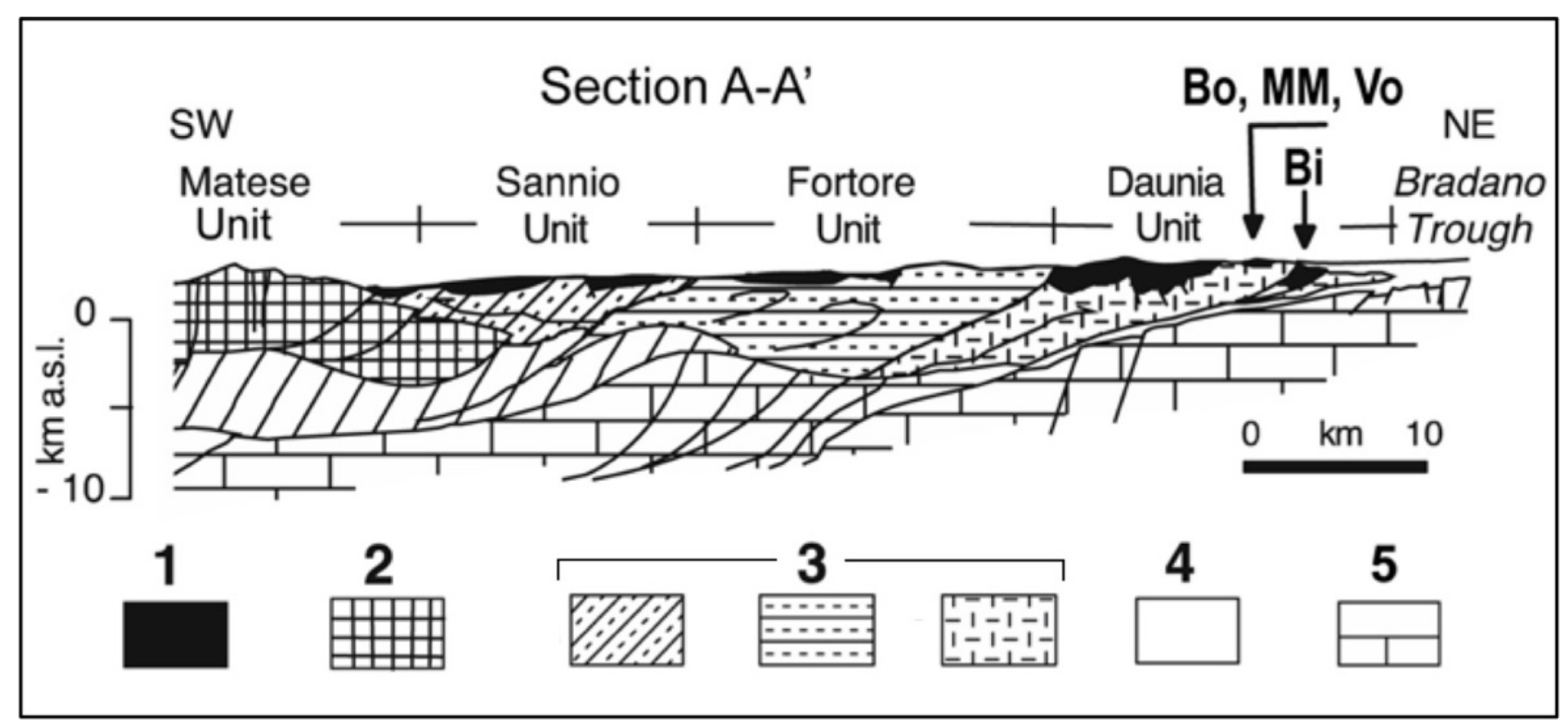

Figure 2. Schematic geological cross-section $\mathrm{A}-\mathrm{A}^{\prime}$ through the northeastern edge of the Sannio-Daunia Apennines within which the studied slopes are located (after [35], modified). Trace of the cross-section shown in Figure 1. Key: (1) PlioMiocenic Silicoclastic Units; (2) Apennine Platform Units; (3) Upper sequences of the Lagonegro-Molise Units: Sannio Unit (left), Fortore Unit. (middle), Daunia Unit (right)-Faeto Flysch outcropping at Bovino (Bo), Motta Montecorvino (MM), Volturino (Vo) and Biccari (Bi) slopes); (4) Bradano Through Unit; (5) Apulian Platform Units. 


\section{Geo-Hydro-Mechanical Settings of the Faeto Flysch in the Daunia Apennines}

\subsection{Paleogeography and Current Geo-Structural Setting of Faeto Flysch}

The location of the sites analysed in this paper is shown in the simplified geological map of Figure 1. For sake of completeness, a schematic structural map of Italy is sketched in the corner of Figure 1 The current geological setting at the selected sites is closely related to the geological history of the eastern sector of the Southern Apennines. This is part of the Apennine-Maghrebian chain, a Neogene to Quaternary thrust belt, verging to the northeast, located in the hanging wall of a west-directed subduction of the AdriaticAfrican lithosphere, under the European plate [36,37]. This chain is bordered, to the east, by the Pliocene-Pleistocene foredeep (Bradano trough) and, to the west, by the Tyrrhenian back-arch basin [38] (Figures 1 and 2).

The Southern Apennine allochthonous nappes derive from the deformation of basin and platform domains within the passive margin of the Adriatic-African plate [34], whose sediments were piled-up, progressively from west to east, into the Apennine chain during the orogenesis. Therefore, the Daunia Unit, including the FAE, deposited in a distal portion of the Lagonegro-Molise basin, is currently located in the lowest and easternmost portion of the chain (Figure 2; [35]). According to the reference geological maps (Foglio Geologico 407 "San Bartolomeo", scala 1:50,000; Progetto CARG, 1989-91 [39,40]), in the Daunia Unit the FAE succeeds to the Red Flysch (FYR) through a gradual transition, and it is overlain by the Toppo Capuana clays (TPC).

According to the literature, the FAE is composed of alternating turbiditic calcarenites, calcilutites and whitish marls, with interlaying clays and bioclastic calcirudites. From bottom to top [41] are recognised marly-clayey and a calcareous-marly members. These authors report that the former member is composed of rather regularly alternating white and yellow marls, calcarenites and greenish to grayish clayey marls, in relatively thin layers (thickness lower than $1 \mathrm{~m}$ ). The latter member, instead, is made of brecciolas and well-cemented bioclastic calcarenites, arranged in layers, and of marly limestones and marls. The underlying FYR [40,42], instead, is constituted by polychromous scaly clays interbedded with calcarenites and calcilutite turbidites (Cretaceous-Miocene [43]). The overlying TPC formation is mainly composed of grey-blue marly clays and clayey-silty marls, well stratified and with occasional thin calcilutites layers.

\subsection{Representative Geo-Hydro-Mechanical Setups of Faeto Flysch and Landslide Mechanisms Recorded at the Regional Scale}

Cotecchia et al. [2] devised the so-called Multiscalar Method for Landslide Mitigation (MMLM) that, moving from slope-scale analyses of the coupled processes that give rise to slope instability, allows one to derive the most recurrent slope factors and failure scenarios within a region of given paleo-geographic origin. The geo-hydro-mechanical setups representative for the region are recalled as $\mathrm{GM}_{\mathrm{i}}$, and the representative landslide mechanisms are recalled as $\mathrm{M}_{\mathrm{i}}$ [44] The authors show that, despite the landscape variability in geologically complex regions, in which diverse set-ups and landslide mechanisms may occur, the hydraulic and mechanical properties of the soils and rocks of the geological formations vary within limited intervals, more limited than expected according to the variability of the geological features. Hence, it can be expected that within any region of single paleogeographic origin, as is the case, for example, for the Daunia Apennines, the number of $\mathrm{GM}_{\mathrm{i}} \mathrm{s}$ and $\mathrm{M}_{\mathrm{i}} \mathrm{s}$ is limited. An important outcome of such a condition is the possibility of identifying a limited number of $\mathrm{GM}_{\mathrm{i}} \mathrm{s}$ and $\mathrm{M}_{\mathrm{i}} \mathrm{s}$, which, on the whole, represent the landslide factors and the landslide features for the region.

Through the application of the MMLM to the Daunia Apennines, Cafaro et al. [44] could identify three main types of geo-mechanical units forming the $\mathrm{GM}_{\mathrm{i}} \mathrm{s}$ of the region. These are mainly formed of a conglomerate-sandy unit, a rocky unit and a soil unit, which alternate in the $\mathrm{GM}_{\mathrm{i}} \mathrm{s}$, as shown in Figure 3. In particular, the rocky unit includes stiff, highstrength materials, such as limestones, sandstones, or marls, locally interbedded with few thin clayey strata, or marly rocks and weakly cemented sandstones. With regard to FAE, 
the rocky units, recalled as $\mathrm{FAE}_{\mathrm{C}}$ below, are represented by limestone strata, several meters thick and locally fractured (Figure 4a). The soil unit (Figure $4 \mathrm{~b}$ ) consists of deformable and weak materials, usually clays or silty clays, which are, in places, fissured, laminated or sheared. In some cases, soil units can also include rocky interbeddings, often fractured, as

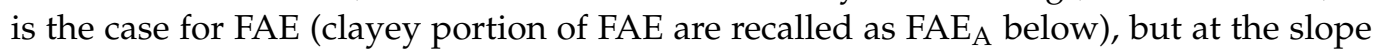
scale their mechanical behaviour is still controlled by the clay portions. The detail of a transitional rocky-clayey FAE unit with abundant folded and fractured rock interbeddings, outcropping at Volturino, is shown in Figure 4d. Soil units are also massively diffuse in the FYR, the TPC and the Sub-Apennine Clays Formation (SCF), which outcrop at some of the pilot sites of reference described below. The conglomerate-sandy units are made up of weakly cemented pebbles with sands or coarse-grained sands, with a lot of pebbles dispersed in them (Figure 4c); they are absent in FAE, whereas they are present, for example, within the Bovino Synthem (BOV), a forechain basin deposit upon which the stable historic centre of Bovino rises.
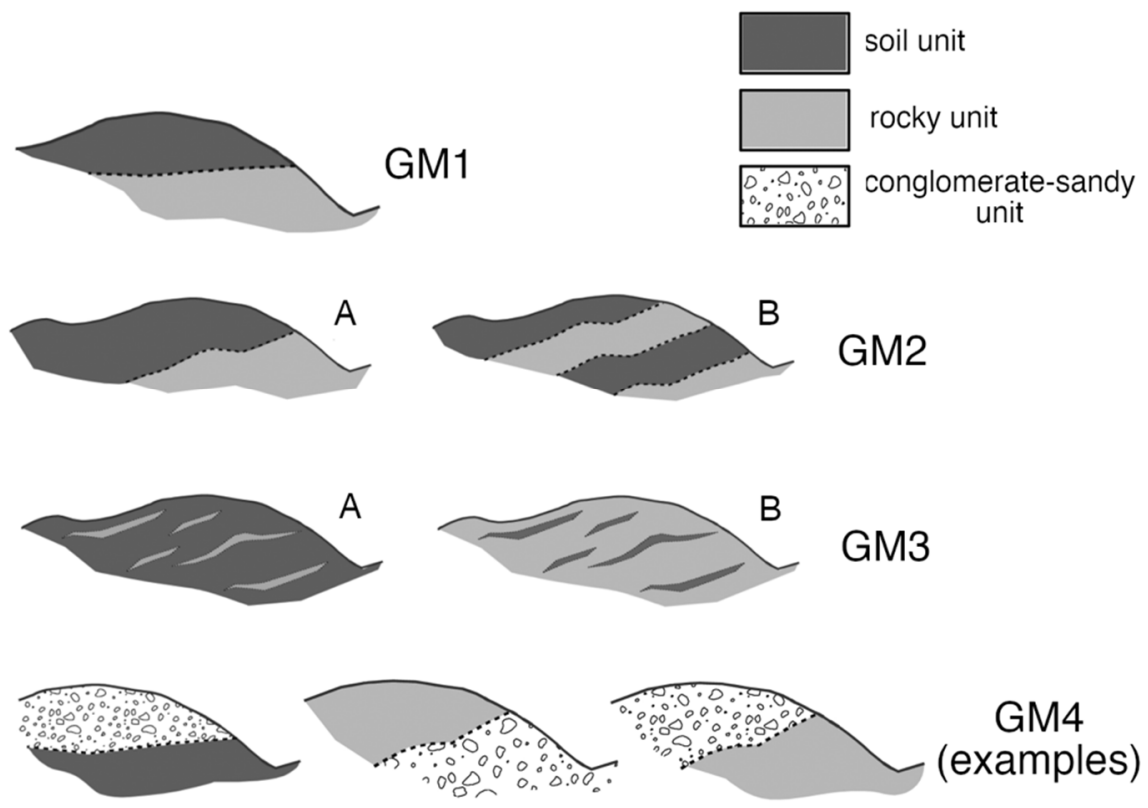

Figure 3. Recurrent geomechanical setups (GMi) in Daunia Apennines (after [44]).

The three units described above are arranged into the four different $\mathrm{GM}_{\mathrm{i}} \mathrm{s}$ (Figure 3) across the Daunia Apennines. These differ for the trend of the contact between the rocky, conglomeratic or soil units. Setup $\mathrm{GM}_{1}$ represents a stack of alternating sub-horizontal rock and soil units. In $\mathrm{GM}_{2}$, instead, the contact between the geomechanical units is dipping; two sub-categories have been identified: single contact between two units $\left(\mathrm{GM}_{2 \mathrm{~A}}\right)$, and multiple contacts between alternating units $\left(\mathrm{GM}_{2 \mathrm{~B}}\right) . \mathrm{GM}_{3}$ identifies all those cases in which disarranged portions of a secondary soil unit are found into a main rock unit $\left(\mathrm{GM}_{3 \mathrm{~A}}\right)$ or vice versa $\left(\mathrm{GM}_{3 \mathrm{~B}}\right)$, usually as a consequence of intense tectonic shearing that occurred during orogenesis. In $\mathrm{GM}_{4}$, a conglomerate-sandy unit is in contact (sub-horizontal or inclined) with either a soil or a rocky unit (some possible configurations of $\mathrm{GM}_{4}$ shown in Figure 3). Regardless of the specific $\mathrm{GM}_{\mathrm{i}}$ setup, all the examined slopes appear to host a significant seepage flow with a groundwater table commonly found at some $4-5 \mathrm{~m}$ b.g.1. [16,44].

Following a thorough site-scale interpretation of the landslide processes at several sites across the Daunia Apennines, seven categories of landslide mechanisms $\mathrm{M}_{\mathrm{i}}$ (Figure 5) classified according to [1], have been identified. Landslide mechanisms part of class $\mathrm{M}_{1}$ are either slides or roto-translational slides, usually deeper than $30 \mathrm{~m}$ and as wide, with mainly retrogressive activity. The sliding surfaces can be either single or multiple and tend to become flatter in the accumulation zone. Clay slides, or mudslides according to Hutchinson [45], fall into class $\mathrm{M}_{2}$. They can have multiple source areas and are usually 
elongate or lobate; they may appear flow-like but also show evidence of sliding, with shear bands up to several metres thick, usually at medium to great depths. Landslide mechanisms of class $\mathrm{M}_{3}$ are earthflows [46], i.e., flow-like movements where both internal shear strains, causing full remoulding of the landslide body, and sliding along multiple discrete shear surfaces coexist [47]. These landslides can be several kilometres long, and their depth is typically around $15 \mathrm{~m}$ or somewhat larger. Composite and complex landslides belong to class $\mathrm{M}_{4}$; they are deep (more than $30 \mathrm{~m}$ ) rotational landslides at their head, evolving into a shallow (less than $10 \mathrm{~m}$ deep) earthflow towards the foot. Finally, some secondary, less commonly recurring landslide mechanisms have also been identified in Daunia, i.e., shallow soil slips $\left(\mathrm{M}_{5}\right)$, slumps or rotational slides $\left(\mathrm{M}_{6}\right)$, and rock falls or toppling $\left(\mathrm{M}_{7}\right)$.
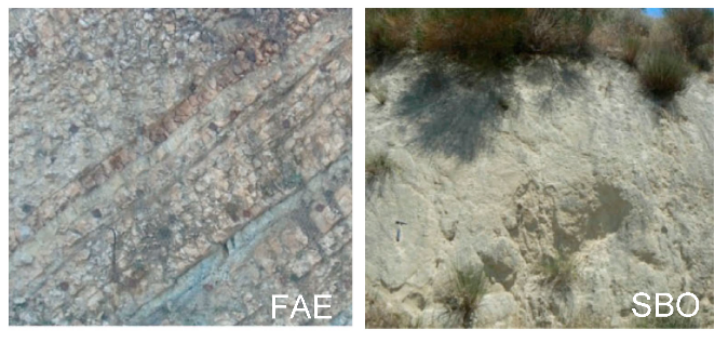

(a)
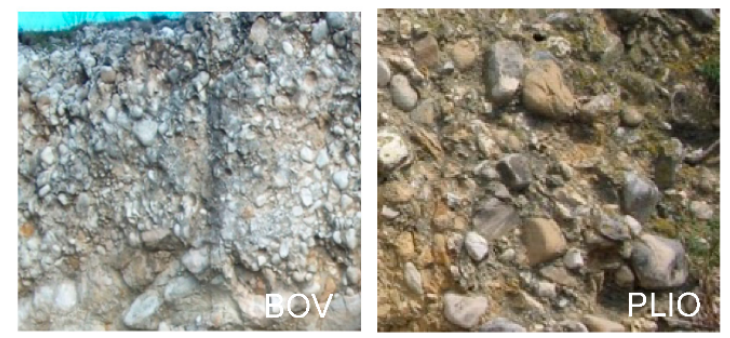

(c)
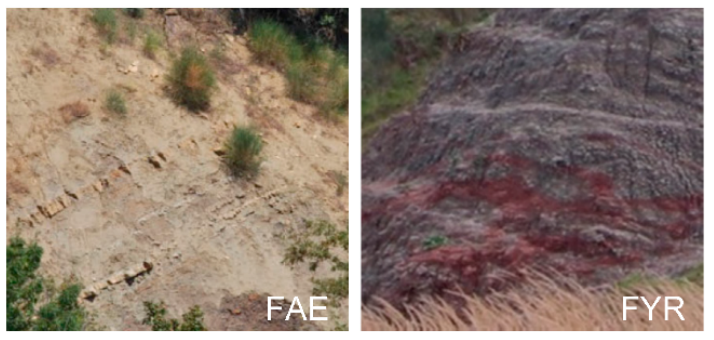

(b)

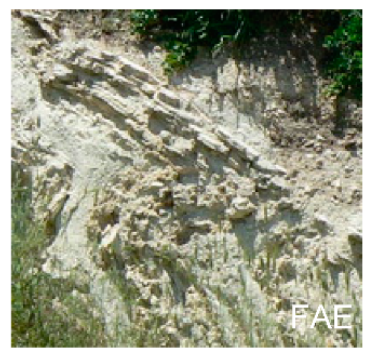

(d)

Figure 4. (a) Rocky; (b) clayey; (c) conglomeratic units (FAE-Faeto Flysch, SBO—San Bartolomeo Flysch, FYR—Red Flysch, BOV-Bovino Synthem, PLIO-Pliocene Conglomerate); (d) transitional rocky-clayey FAE unit with fractured rock layers.
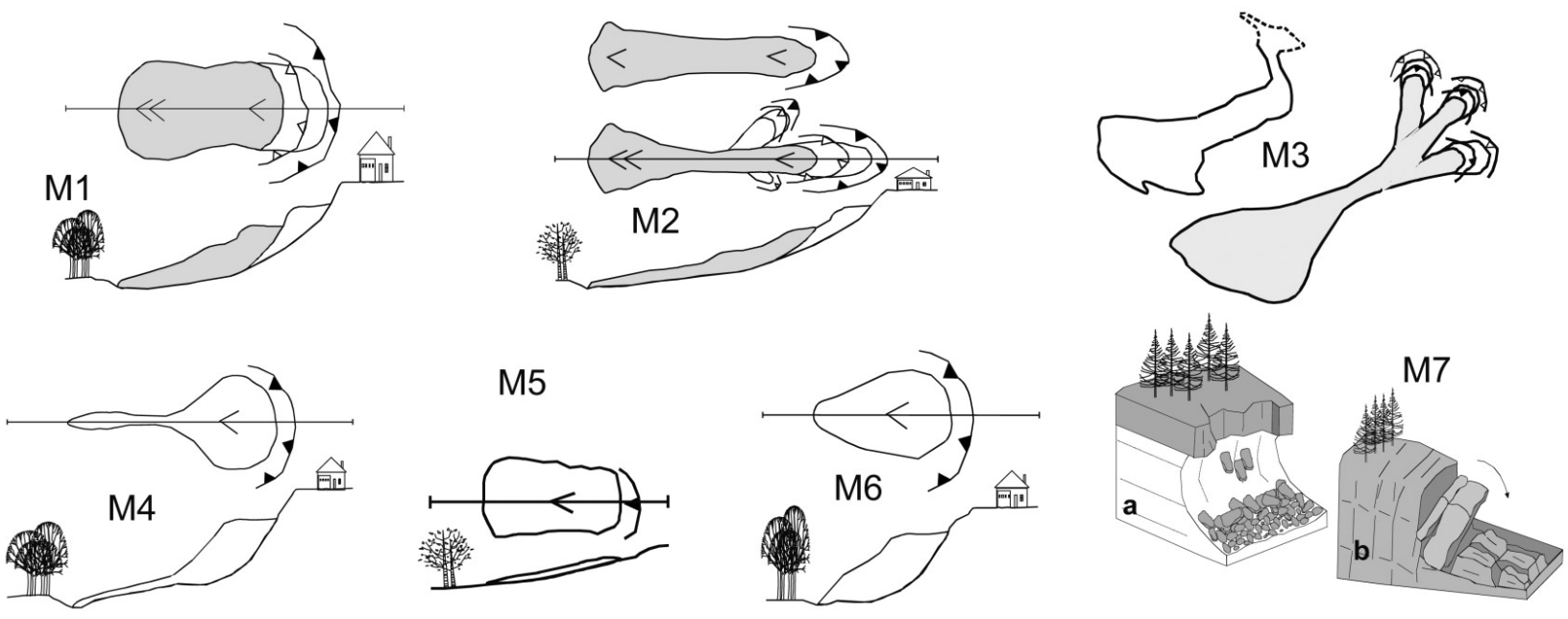

Figure 5. Recurrent landslide mechanisms (Mi) in Daunia Apennines (after [44]). 


\section{Description of the Selected Sites}

\subsection{Motta Montecorvino}

The town of Motta Montecorvino (average altitude $662 \mathrm{~m}$ a.s.l.) rises on a hilltop where $F A E_{C}$ overlies $F A E_{A}$, which in turn lies upon the FYR clays through a sub-horizontal contact (Figure 6a,b); as such, the geomechanical setup can be classified as $\mathrm{GM}_{1}$. Due to the peculiar setup, the topmost rocky $\mathrm{FAE}_{\mathrm{C}}$ unit, with abundant discontinuities, is likely to host a seepage domain, as implied by the evidence of some springs close to the lithological contact with the base clayey units of $\mathrm{FAE}_{\mathrm{A}}$ and FYR. Furthermore, pore water pressures logged at depth showed piezometric levels as high as $3 \mathrm{~m} \mathrm{b.g.l.} \mathrm{The} \mathrm{results} \mathrm{of}$ geomorphological studies and of the campaigns of ground investigations carried out for the design of stabilisation works in the area are detailed in [48].

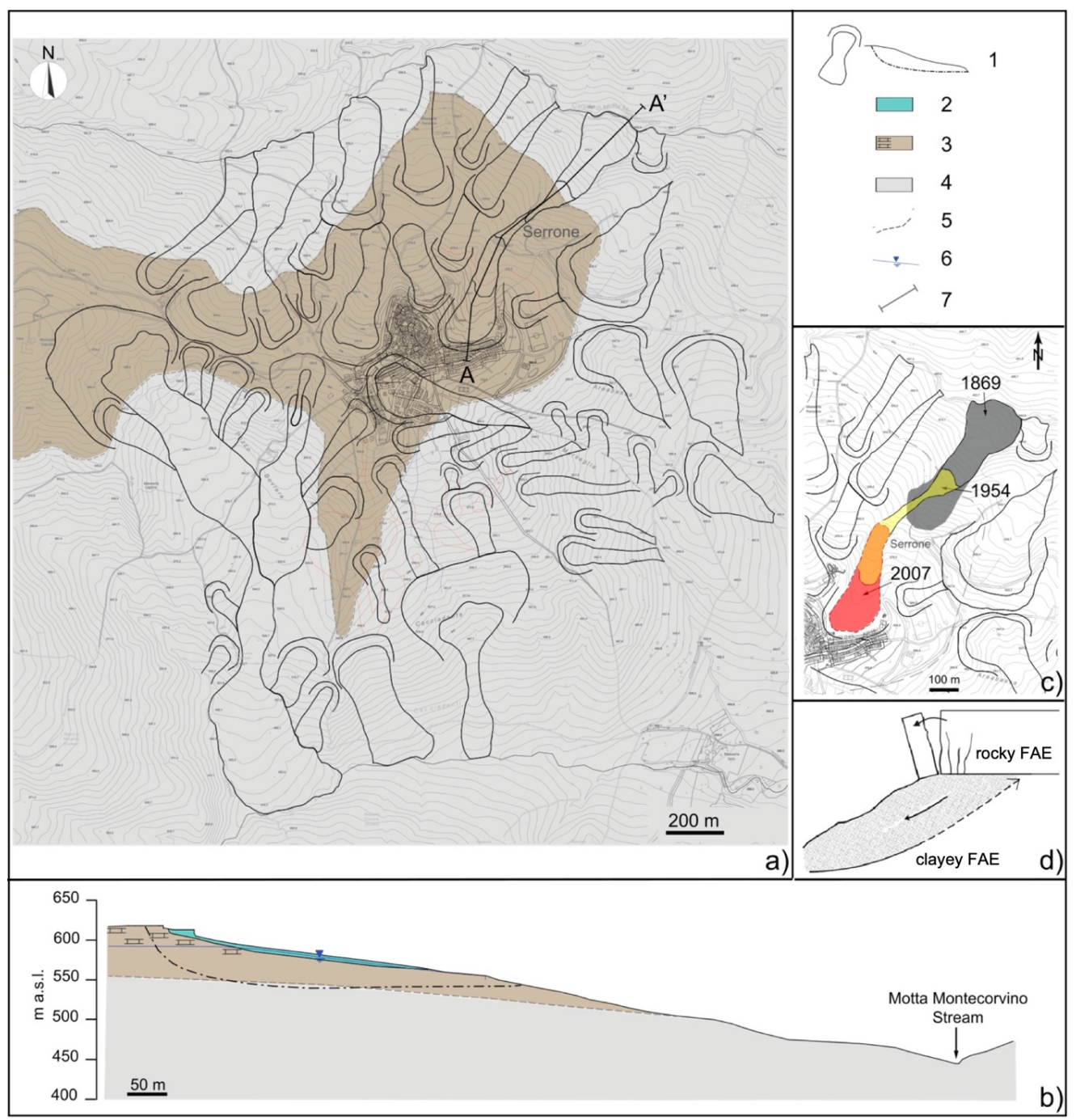

Figure 6. Motta Montecorvino: (a) geological map; (b) longitudinal cross section of Serrone landslide; (c) schematic geomorphological evolution of Serrone landslide from 1869 and 2007; (d) scheme of retrogressive evolution involving rocky Faeto Flysch. Key: (1) landslide bodies in map (left) and cross-section (right); (2) backfill; (3) Faeto Flysch (symbols indicate rocky portion); (4) Red Flysch; (5) stratigraphic contact; (6) groundwater table; (7) trace of the longitudinal cross-section.

As shown in Figure 6a, the town centre is almost completely surrounded by landslide bodies; 42 landslides have been identified in the area, through interpretation of multitemporal aerial photographs [48]. Some of them, especially in the north side of the town, interact with the built environment. One of the main landslide processes, the Serrone 
landslide, whose geomechanical longitudinal cross-section is sketched in Figure 6b, is about $700 \mathrm{~m}$ long from crest $(640 \mathrm{~m}$ a.s.l.) to toe $(450 \mathrm{~m}$ a.s.l.) and $30 \mathrm{~m}$ wide at the narrowest point, develops in the NNE direction from the city centre. The currently active mechanism can be classified as $\mathrm{M}_{1}$, according to the classes reported in Figure 5, i.e., a compound clay slide with a rotational-translational failure mode (maximum depth 40-50 m b.g.l.) and retrogressive evolution. It involves reactivation of pre-existing shear bands, remnants of ancient landsliding, likely to host remoulded $\mathrm{FAE}_{\mathrm{A}}$ clay with even poorer strength properties with respect to the parent soil.

In fact, previous studies [48], including FEM and LEM analyses of the slope, have shown that Serrone, similar to most of the landslides in the Motta Montecorvino area, follows a specific path of activation and evolution (Figure 6c), giving rise to a complex phenomenon as follows. In the past, first-time failure (class $\mathrm{M}_{1}$, grey area in Figure $6 \mathrm{c}$, dating back to 1869) was triggered at the foot of the slope by stream erosion, which seems to be also another common factor for the instability of slopes in the Daunia Apennines. Subsequently, a composite mechanism was activated, due to unloading at mid-slope, consisting of a rotational failure in the depletion zone evolving into an earthflow downslope (class $\mathrm{M}_{4}$, yellow-orange area in Figure 6c, dating back to 1954). Finally, the poor mechanical properties of the clayey $\mathrm{FAE}_{\mathrm{A}}$ facilitate the upslope evolution of the shear band until the upper $\mathrm{FAE}_{\mathrm{C}}$ unit is involved in a toppling-like mechanism, due to lack of support by the weaker $\mathrm{FAE}_{\mathrm{A}}$ substratum (Figure $6 \mathrm{~d}$ ), giving rise to the currently active mechanism (class $\mathrm{M}_{1}$, orange-red area in Figure 6c). The results of LEM calculations, in particular, show that post-peak shear strength is mobilised in the $\mathrm{FAE}_{\mathrm{A}}$ for the active body of the Serrone landslide, hence confirming that the current activity is actually a reactivation of ancient landsliding.

\subsection{Volturino}

The old town of Volturino (735 $\mathrm{m}$ a.s.l.) lies on an outcrop of calcarenitic $\mathrm{FAE}_{\mathrm{C}}$, in contact to the west with the TPC clays and to the east with the clayey $F_{A E}$, as shown in Figure 7a. Moving further west, the TPC formation is overlain by another sequence of $\mathrm{FAE}_{\mathrm{A}}-\mathrm{FAE}_{\mathrm{C}}$. Therefore, a $\mathrm{GM}_{2 \mathrm{~B}}$ geomechanical setup can be envisaged. At greater depth, the SCF formation is found, outcropping east of the town.

Among the landslides surrounding the historic centre, the most important is the Fontana Monte $[23,24,49]$, bordering the town to the west, so called for the presence of a spring emerging at the overthrust contact between the TPC and $\mathrm{FAE}_{\mathrm{C}}$. This is a large, slow-moving, deep-seated landslide, about $1 \mathrm{~km}$ long and $300 \mathrm{~m}$ wide, with maximum depth $45-50 \mathrm{~m}$, mainly developing in the marly clays of TPC, with the toe in the Giardino stream and having an average inclination of $9^{\circ}$. The longitudinal cross-section of the Fontana Monte landslide, depicted in Figure $7 \mathrm{~b}$, shows that the landslide body develops almost totally in the TPC layer; it can be classified as a deep clay slide, i.e., $\mathrm{M}_{2}$ class. This site was quite extensively studied in the context of research projects carried out within either national or European funding frameworks. Details about the procedures and the results of geomorphological analyses, field monitoring and site and laboratory testing carried out on the slope are extensively discussed in [23,49].

Geomorphological studies based on old topographic maps of the area revealed that the landslide was already active in the late nineteenth century, implying that the current slope movements represent a reactivation along pre-existing deep shear bands. At present, the geometry of the shear band has been reconstructed based on inclinometer data and evidence of disturbed soil bands in borehole cores at depth [23] (Figure 7b). In particular, inclinometer I1 (Figure $7 \mathrm{~b}$ ) indicates that the current evolution of the landslide is retrogressive and affecting the crest of the hill, thereby causing damage on buildings and roads. 

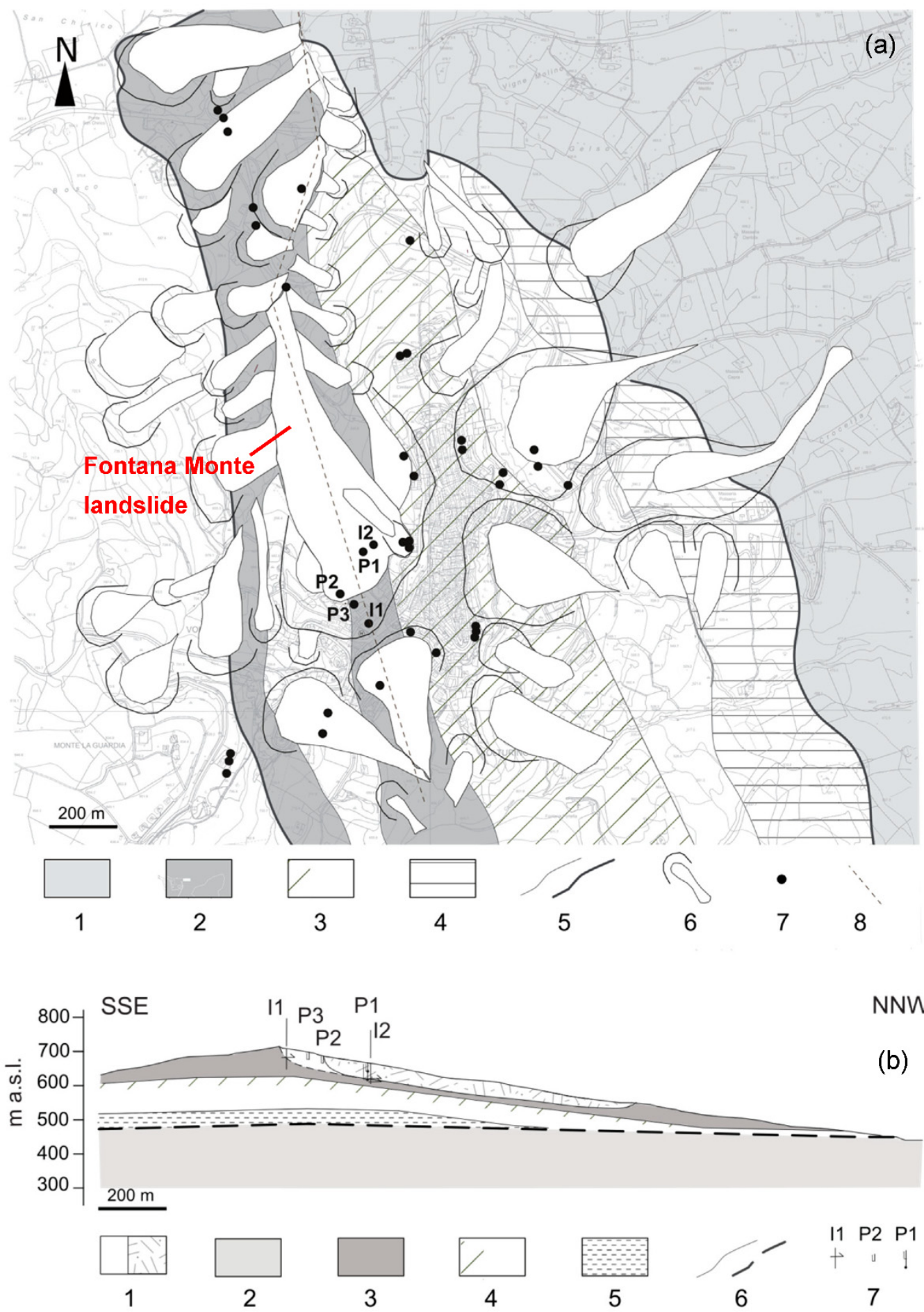

Figure 7. Volturino: (a) geological/geomorphological map; (b) longitudinal cross-section of Fontana Monte landslide (after [23,49]; modified). Key of (a): (1) Sub-Apennine clays; (2) Toppo Capuana clays and marls; (3) Faeto Flysch (diagonal lines indicate rocky portion); (4) Red Flysch; (5) stratigraphic (left) and tectonic (right) contact; (6) landslide body and crown; (7) boreholes; (8) trace of longitudinal cross section. Key of (b): (1) landslide body (solid white for retrogression area); (2) Sub-Apennine clays; (3) Toppo Capuana clays; (4) Faeto Flysch (diagonal lines indicate rocky portion); (5) Red Flysch; (6) stratigraphic (left) and tectonic (right) contact; (7) field investigations: inclinometer (left), standpipe (middle), Casagrande piezometer (right). 
Casagrande piezometers installed at depth (25-49 m), also shown in Figure $7 \mathrm{~b}$, give evidence of a seepage flow in the slope, with a water table not deeper than $4 \mathrm{~m}$ b.g.l. in summer and autumn. The piezometric level was found to rise as much as $1.5 \mathrm{~m}$ in winter-spring. Such pore water pressure oscillations, causing a concurrent variation of the available shear strength, correlate well with the observed seasonal reactivations of the landslide, as shown by the inclinometer readings in various periods of the year [23] and as corroborated by the results of FEM analyses implementing the steady state piezometric regime measured in the slope in different seasons [24].

Even though the body of the Fontana Monte landslide solely develops into the TPC clays, the hydraulic properties of the surrounding $\mathrm{FAE}_{\mathrm{C}}$ have a decisive role in the recurrent, seasonal acceleration of the landslide, given the peculiar GMH setting. In fact, the $\mathrm{FAE}_{\mathrm{C}}$, rich in fractured rock layers and inclusions, exhibits a slope-scale permeability much larger than the fine grained TPC layer involved in the landslide. Hence, seasonal rainfall infiltration through the rock fractures causes pore water increase down to great depths in the $\mathrm{FAE}_{\mathrm{C}}$ aquifer. The latter, in turn, feeds the TPC from the bottom and the sides, imposing the resulting high piezometric levels as a hydraulic boundary condition and, as a consequence, constituting a predisposing factor for the instability of the slope.

\subsection{Bovino}

The old town of Bovino ( $620 \mathrm{~m}$ a.s.l.) is located on the most competent part of the Pliocene wedge-top deposits belonging to the Bovino Synthem (BOV), made of grainsupported conglomerates and medium-coarse grained sandstones, which lies unconformably upon hundreds of metres of FAE. Located SSW of the historic centre, the Pianello slope (Figure 8a), where the most recent urban expansion of the town has occurred, hosts a complex basin of slow-moving landslides, leading to widespread damage of buildings [18,50,51]. An NE verging thrust fault, SW dipping, and a WNW-ESE oriented anticline, plunging to the north, are found in the Pianello area, as features of the recent orogenic activity (Figure 8a). Among the test sites presented in this paper, Bovino is the most extensively studied. Campaigns of ground investigation and field monitoring, as well as surveys and analyses of landslide-induced damage of buildings, were conducted in the context of research projects funded within either national or European frameworks, leading to thorough characterisation of the Pianello slope. Details of these studies and of their results are reported in [17,18,50-52].

As shown in the figure, the axis of the anticline is almost coincident with the longitudinal axis of the main landslide body. The $\mathrm{FAE}_{\mathrm{A}}$ outcrops at the Pianello slope, while $\mathrm{FAE}_{\mathrm{C}}$ is found at its flanks. Actually, the transition between the two units is gradual, with clay predominantly found at the core of the anticline, getting richer in calcarenite moving towards the limbs of the fold and the ground surface. The top of FYR, outcropping farther south of the town, is expected to be found at least $60 \mathrm{~m}$ b.g.l. under the $\mathrm{FAE}_{\mathrm{A}}$. $\mathrm{A} \mathrm{GM}_{2 \mathrm{~A}}$ setup, due to the inclined contact between $\mathrm{FAE}_{\mathrm{C}}$ and $\mathrm{FAE}_{\mathrm{A}}$, is thus recognised in the area of interest. Across the whole slope, the shallowest part of $\mathrm{FAE}_{\mathrm{A}}$ consists of an altered cover $\left(\mathrm{FAE}_{\mathrm{A}, \mathrm{W}}\right)$, due to either weathering or tectonic shearing, with a calcarenite content reflecting that of the underlying unaltered unit (i.e., increasing towards the flanks of the main landslide).

The main landslide body ( $A$ in Figure 8a,b) in the Pianello slope can be classified as $\mathrm{M}_{1}$, i.e., it is a deep, slow roto-translational slide showing signs of retrogressive activity. The shear band runs through the $\mathrm{FAE}_{\mathrm{A}}$, possibly skimming the top of the FAE-FYR transition, and is at least as deep as $60 \mathrm{~m}$ b.g.l. The accumulation zone of a shallower secondary landslide body (B in Figure 8a,b), interacts with the head of the main landslide. Apparently, the head of landslide B also involves the part of the FAE substratum richer in calcarenite inclusions, in a similar fashion as observed at other sites (e.g., Motta Montecorvino, Section 3.1) causing significant damage to the overlying buildings. 


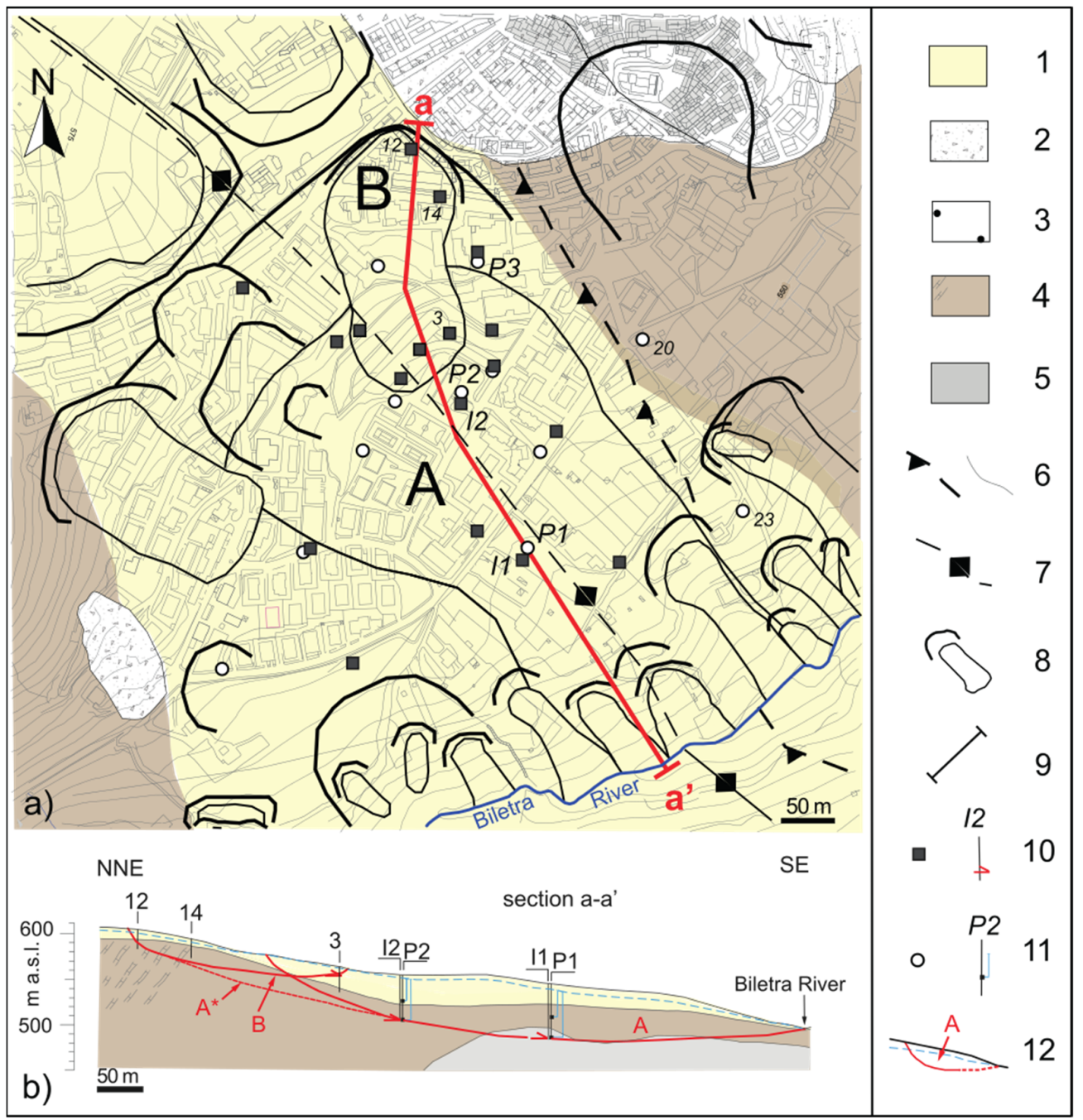

Figure 8. Bovino: (a) geological/geomorphological map with location of boreholes; (b) longitudinal cross section of Pianello landslide. Key: (1) altered Faeto Flysch cover; (2) debris; (3) Bovino Synthem; (4) Faeto Flysch (symbols indicate rocky disrupted strata); (5) Red Flysch; (6) thrust fault (left) and stratigraphic contact (right); (7) anticline axis; (8) landslide crown and body; (9) trace of cross section; (10) boreholes hosting inclinometer in map (left) and cross-section (right), arrow indicates the depth of shearing; (11) boreholes hosting piezometer in map (left) and cross-section (right), depth of cell and corresponding water head are also shown; (12) cross-section of landslide body and piezometric surface (failure surface dashed when inferred).

Previous back-analyses of the stability of Pianello slope [52] showed that the shear band of landslide A is likely to have evolved retrogressively, so as to incorporate body B in a single, complex landslide mechanism corresponding to body $A^{*}$ in Figure $8 \mathrm{~b}$. In the same study, FEM analyses confirmed that, as in other cases in the Daunia Apennines, failure initiates at the toe, due to stream erosion, and subsequently develops retrogressing into the $\mathrm{FAE}_{\mathrm{A}}$, due to the poor shear strength of the latter, and that the current activity actually is a reactivation of previous movements along pre-existing shear bands, along which the feeble post-peak shear strength of $\mathrm{FAE}_{\mathrm{A}}$ is mobilised.

As suggested by the displacement profile of inclinometer I2 (Figure 9a) located approximately in the centre of the Pianello slope (Figure 8a,b), the kinematics of body A resembles a quasi-rigid body motion, with sliding occurring on a clearly-defined shear band, at approximately $47 \mathrm{~m}$ b.g.l., and negligible shear deformation of the bulk of the landslide mass. Such a particular displacement field has some notable consequences on the pattern of landslide-induced damage on buildings, as observed by Palmisano et al. [17,18]. 
In fact, field surveys revealed that many buildings laying on the main landslide body of the Pianello slope were left practically undamaged by the landslide activity, regardless of their structural and foundation layout, while those resting behind the crown and near the flanks of the landslide were significantly affected, the former experiencing mainly differential settlements due to retrogression of the landslide, the latter, in addition, undergoing torsional distortion.
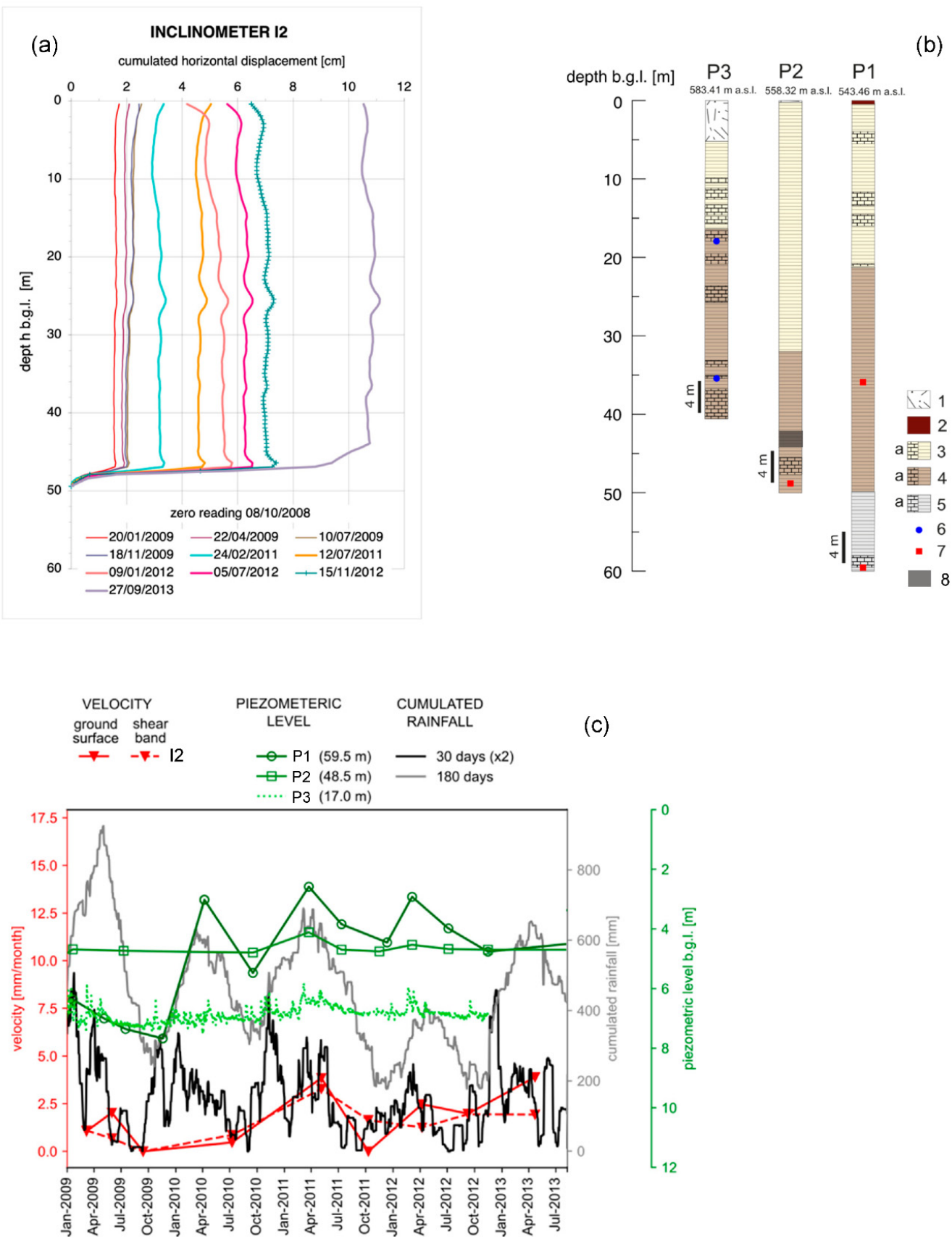

Figure 9. Bovino: landslide processes. (a) Inclinometer I2; (b) borehole logs P1, P2 and P3; (c) effect of cumulated rainfall on slope movements and porewater pressure. Key of (b): (1) made ground; (2) topsoil; (3) altered cover of clayey Faeto Flysch; (4) clayey Faeto Flysch; (5) Faeto Flysch-Red Flysch transition (symbols indicate calcarenitic levels); (6) electric piezometer; (7) Casagrande piezometer; (8) signs of remoulding.

Casagrande piezometers installed in the slope measured high pressure heads down to great depth. As in other cases where the FAE is involved (e.g., Volturino, Section 3.2), the 
landslide exhibits seasonal accelerations related to the oscillation in the piezometric level at depth. Figure $9 \mathrm{c}$ reports the piezometric level, in terms of depth of the groundwater table, measured in two Casagrande piezometers installed at depth $(59.5 \mathrm{~m}$ and $48.5 \mathrm{~m}$ b.g.l.) in boreholes P1 and P2 (Figure 9b) close to the axis of the slope (Figure 8a,b), i.e., in the core of the most clayey FAE $\mathrm{A}_{\mathrm{A}}$ unit, and in one electric cell (borehole P3, Figure 9b) located next to the head of the landslide body (Figure 8a), in an area where the FAE is rich in fractured calcarenite. To show the connection between the climate and the slope activity, the cumulated 180- and 30-day rainfall and the evolution of displacement rate measured in inclinometer I2, both at the surface and at the shear band, are also plotted in the Figure 9c.

The piezometric head measured by the Casagrande cells in the centre of the slope is remarkably high (up to $2.5 \mathrm{~m}$ b.g.l.) and shows fluctuations as large as $2 \mathrm{~m}$, which seem to be synchronous with the 180-day cumulative rainfall. The continuous measurements of pore water pressure in the electric cells right out of the landslide body, instead, show high frequency and fairly limited oscillations, whose peaks, as high as $1 \mathrm{~m}$, seem more related to the 30-day rainfall curve, hence suggesting a much prompter hydraulic response to weather in that part of the slope. The landslide activity, illustrated by the displacement rate of inclinometer I2, seems also to be synchronous with the 180-day cumulative rainfall, with maximum rates occurring in late winter-early spring, which are hence connected to the observed oscillations of the pore water pressures at depth. The dependency of the observed reactivation of the slope movements with the peaks of the pore water pressures was also confirmed by previous FEM analyses of the slope [52].

In addition to the poor mechanical properties of the clayey layers of FAE, discussed later in Section 3, the high piezometric levels at depth at Bovino represent an additional internal factor predisposing the slope to instability. As in the case of Volturino, discussed in Section 3.2, the soil fissuring and the abundance of fractured rock layers hosting a significant seepage flow in the FAE, particularly close to the crest and in the flanks of the slope, renders the landslides prone to reactivation due to the seasonal oscillation of the pore water pressures, induced by rainfall infiltration not only directly at the ground surface of the landslide body, but also on its flanks This is because the hydrogeological features of the whole hill-slope are such that the water infiltrating in the sloping flanks of the landslide body contributes to the recharge of the seepage domain in the slope portion hosting the deep landslide body and to the corresponding high piezometric heads, detrimental for the slope stability.

\subsection{Biccari}

The reconstruction of the GHM setup and landslide mechanism active in the area of Lago Pescara, some $3 \mathrm{~km} \mathrm{SW}$ of the historic centre of Biccari, is part of ongoing research, whose results to date are discussed below. Lago Pescara (903 $\mathrm{m}$ a.s.l.) is a lake with a maximum depth of about $5 \mathrm{~m}$, originating in the depletion zone of a large ancient earthflowlike landslide. A reinforced concrete gravity wall ( $3.4 \mathrm{~m}$ tall, including a $1.0 \mathrm{~m}$ foundation) was built in the 1970s to raise the maximum water level in the lake. The map shown in Figure 10 indicates that the geological formation in the area of interest extensively consists of FAE to the west, unconformably underlain by the SCF clays. Both formations, particularly the SCF, are locally covered by Quaternary detrital deposits; the toe of the main landslide develops NE through the overthrust.

The major landslide is $2.3 \mathrm{~km}$ long from crown to tip and around $250 \mathrm{~m}$ wide at its minimum; the dimensions of the main scarp (700 $\mathrm{m}$ wide, $290 \mathrm{~m}$ long and $140 \mathrm{~m}$ tall) give an idea of the amount of soil mass involved in the landslide. From geomorphological considerations, the latter appears to belong to class $\mathrm{M}_{4}$ of those recurrently found in the Daunia Apennines (Section 2.2), i.e., a rather deep rotational slide at the head, evolving into an earthflow towards the toe. 


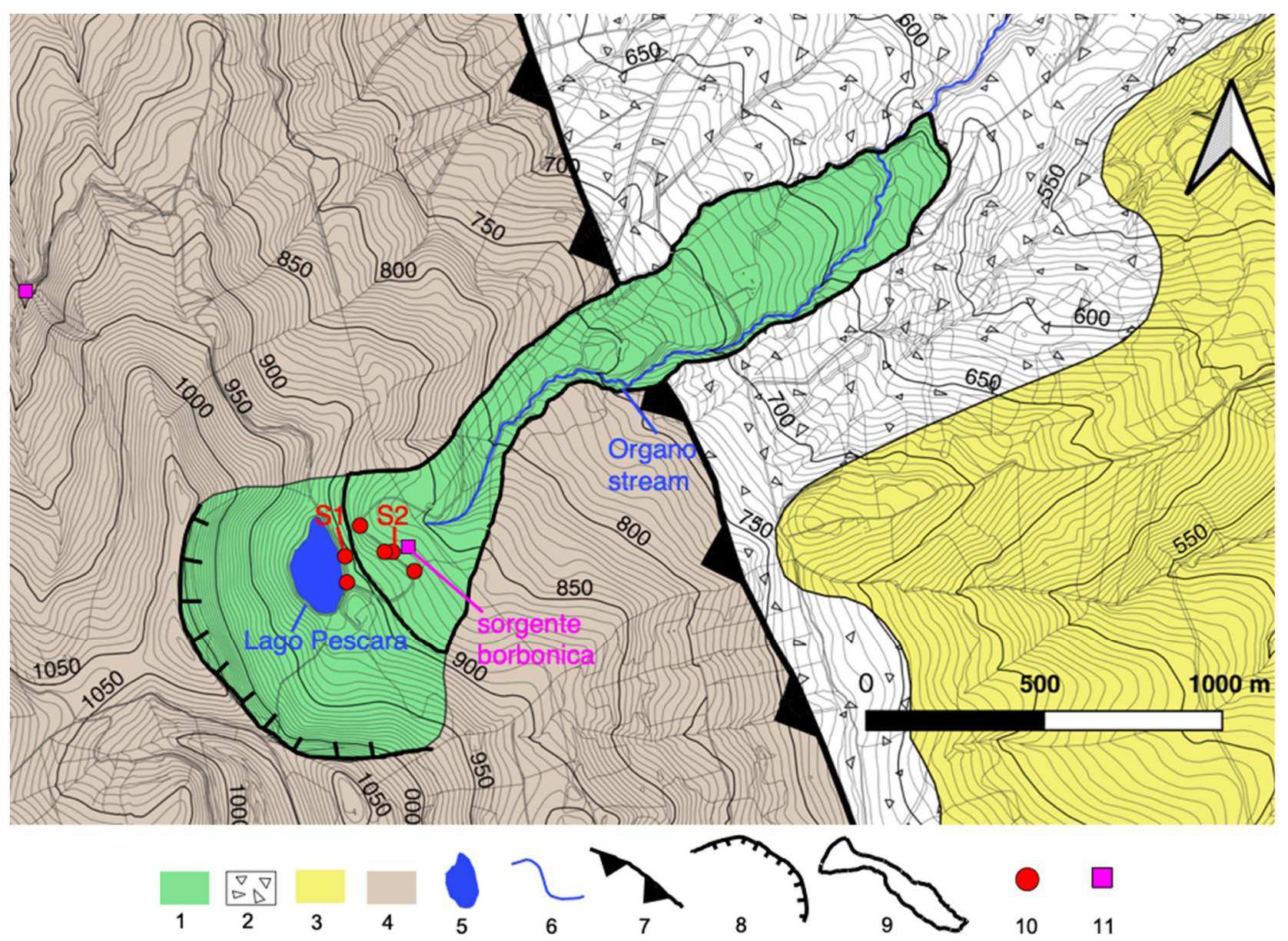

Figure 10. Biccari: geological/geomorphological map. Key: (1) earthflow, (2) detritus, (3) Sub-Apennine Clays, (4) Faeto Flysch, (5) Lago Pescara, (6) Organo stream, (7) overthrust, (8) landslide crown, (9) landslide body, (10) borehole, (11) spring.

The stratigraphic logs of two boreholes performed in the proximity of the lake (Figure 11) show that the FAE is locally covered by a debris layer, most probably of landslide origin. The thickness of the debris cover, approximately 9-11 m next to the lake, decreases downslope. From this evidence, a $\mathrm{GM}_{2}$ setup with dipping contact can be hypothesised. As inferred from the borehole logs, in the area involved in the earthflow, the FAE is mainly fine-grained, with dispersed sand, showing frequent calcareous and marly interlayers or inclusions. Recent geological surveys suggest that the FAE becomes predominantly rocky in the area surrounding the main landslide body, which explains the slope gradients as high as $30^{\circ}$ in the depletion zone. Further walkovers and inclinometer data suggested the existence of many active relatively shallow slides in the slope immediately east of the lake. Readings of inclinometers installed in boreholes S1 and S2 (Figure 11) pointed out the occurrence of sliding at the bed of the overlying debris cover, although deeper and slower landslide movements involving the FAE substratum cannot be excluded at this stage of investigation.

Various pieces of evidence show that the slope of Lago Pescara hosts a complex seepage domain, mainly occurring through the fractured rocky layers of FAE, with localised springs both in the ridge west of the lake and downslope. This is the case, for example, of the "Sorgente Borbonica" (Figure 10), which provides fresh water captured and channelled towards the town centre. Hydrological investigations suggest that the lake itself is fed by fresh water spilling from springs at the centre of the lake, more than by water runoff. Furthermore, the debris cover is likely to be the location of a shallow seepage domain, fed by both rainfall infiltration and local flows coming from the aforementioned deeper FAE aquifer. The high piezometric levels (only locally deeper than $5 \mathrm{~m}$ b.g.l.) characterizing the 
complex seepage in the slope and measured by means of standpipes in the depletion zone, represent an internal predisposing factor to landsliding.

s1

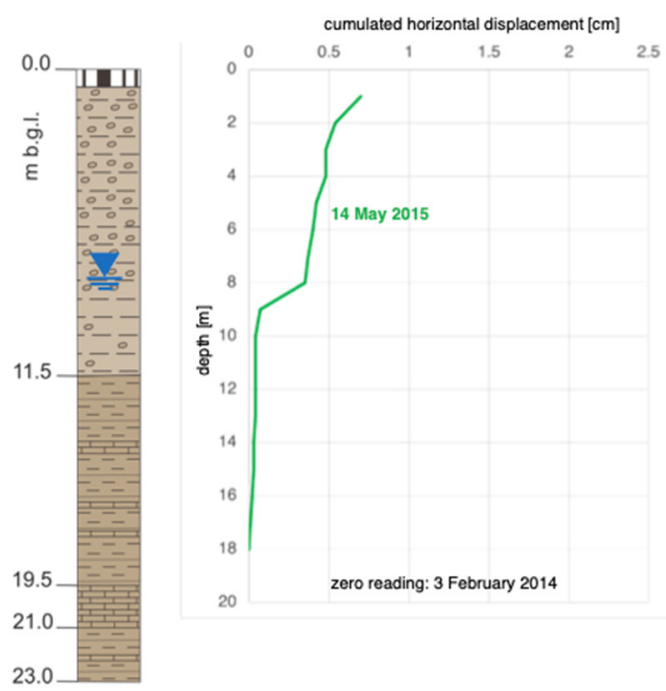

S2

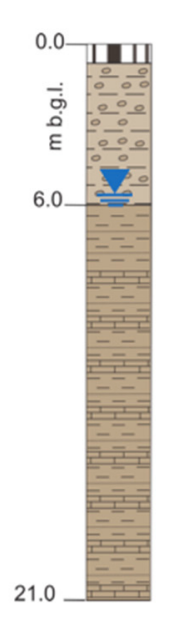

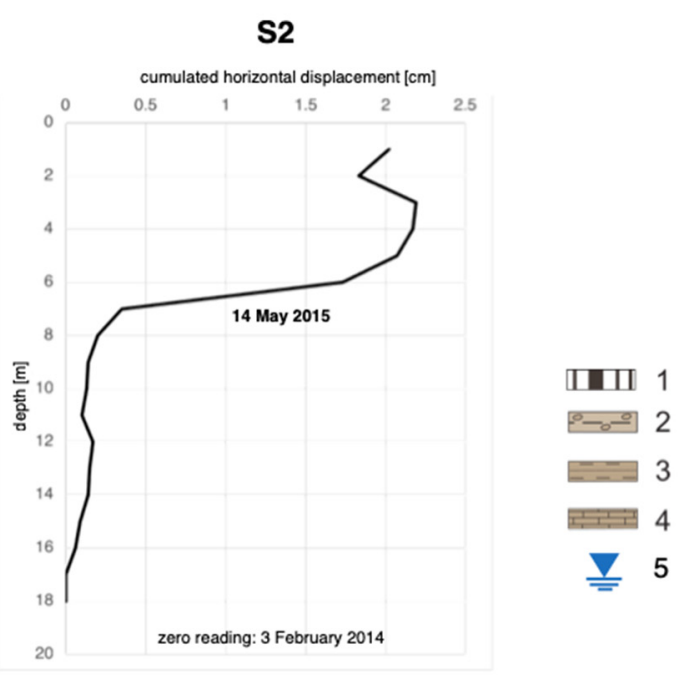

Figure 11. Biccari: borehole logs and inclinometers S1 and S2. Key: (1) made ground, (2) debris, (3) Faeto Flysch, (4) calcareous-marly levels; (5) indicative piezometric level.

\section{Variability of Faeto Flysch Geotechnical Properties}

The geotechnical properties of FAE are presented below, as inferred from samples collected during past campaigns of ground investigations, carried out at the sites described in Section 3, mostly for the design of landslide mitigation measures. Only for Bovino (Section 3.3) and Volturino (Section 3.2), was a plentiful set of data retrieved, including those data collected in the context of research projects funded within either national or European frameworks.

Following the MMLM outlined in Section 2.2, this paper aims at illustrating, at the regional scale, the cause-effect relation between slope factors and observed landslide mechanisms, moving from the results obtained in previous studies at the slope scale. The detailed description of the tests and procedures employed in those studies is not covered in the present paper because, for each examined site, details of the investigation procedures and of the results can be found in the references provided in Section 3. For the case of Biccari, which is part of an ongoing investigation, the geotechnical data were acquired through standard soil classification and direct shear tests. Some geotechnical data available from another site in the Daunia Apennines, Carlantino (Figure 1), despite not being among those described above, are also included in the analysis, for sake of completeness. The results presented in this section highlight both the variability of the material and the common traits in terms of hydro-mechanical properties of FAE at the various sites.

Undisturbed borehole sampling could be carried out only in the soil portions of the FAE units (either $\mathrm{FAE}_{\mathrm{A}}$ or $\mathrm{FAE}_{\mathrm{C}}$ ), which, however, represent the portions of the slope that are mostly the location of failure progression. In the plots presented below, different symbols are used to distinguish the various sites, and, since in most cases, the transition from $F A E_{C}$ to $F A E_{A}$ is gradual, lighter colour shades indicate an increasing rocky content for each site. For the sole case of Bovino, hollow symbols are used for the altered cover of $\mathrm{FAE}_{\mathrm{A}}$ (see Section 3.3).

Grain size distribution (GSD) curves, only available for Bovino and Biccari, plotted in Figure 12, provide evidence of the remarkable heterogeneity of FAE soils. The FAE samples taken at Bovino were characterized by quite a high fines content, with combined silt and clay fractions ranging from $70 \%$ to $99 \%$, allowing the soil to be classified as silty clay or clayey silt, with some sand. On average, the few deep samples collected from 
the centre of the Pianello slope, i.e., in the hinge of the anticline, embodied relatively higher clay and lower silt content, while the opposite was true for samples from the altered cover in the same part of the slope. As expected, due to increased heterogeneity of the formation, samples picked farther from the centre of the slope, where calcarenite layers and inclusions tend to be more frequent and persistent, exhibited more dispersed GSD curves, lying in the shaded area in Figure 12, with 40-50\% silt, up to 30\% sand and clay fraction varying accordingly.

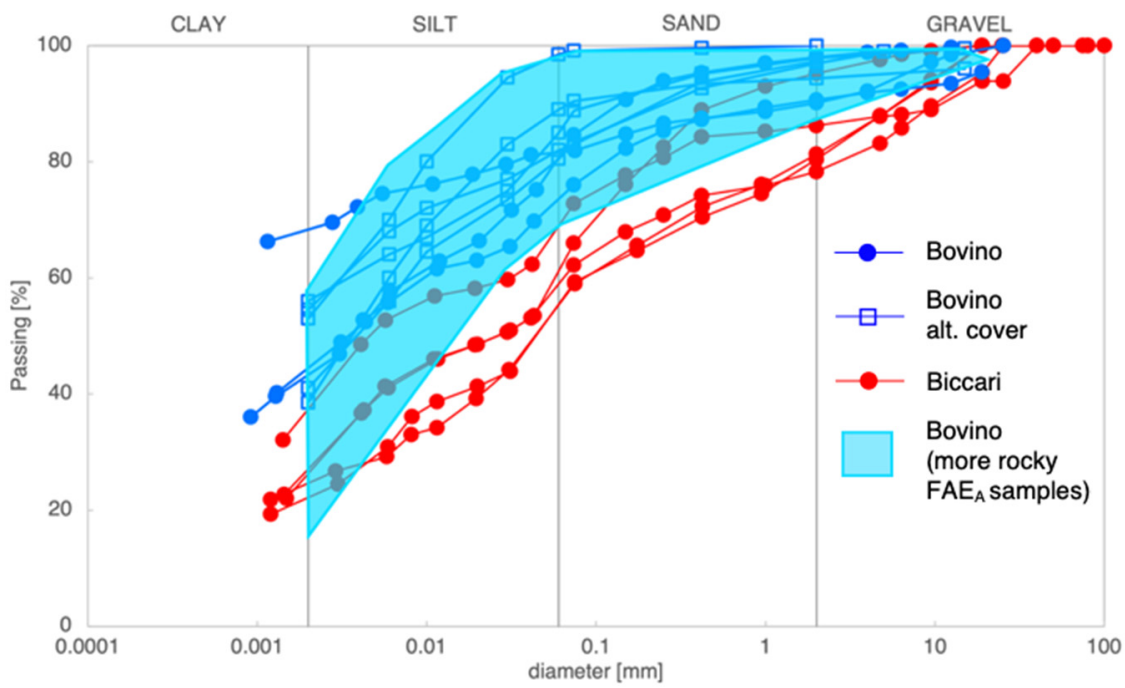

Figure 12. GSD curves for Faeto Flysch at Bovino and Biccari.

The GSD of the FAE samples from Biccari, as shown in the figure, was still finesdominated (clay and silt in the range of 58-70\%), although with an increased coarse-grained fraction with respect to Bovino. A non-negligible gravel fraction, as high as $22 \%$, is likely to indicate a gradual transition with the overlying debris layer, which presumably originated from ancient landsliding involving the FAE substratum, rich in fractured calcarenite layers.

The mineralogical composition of the soil portion of FAE, as measured by X-ray diffraction performed on four samples collected at various depths in Bovino, is shown in Figure 13a,b. Two of the examined samples (52.3 $\mathrm{m}$ and $57.6 \mathrm{~m}$ b.g.l.) came from the bottom of the deepest of all boreholes, close to the centre of the slope (P1: Figures 8a and 9b), which might have intercepted the FAE-FYR transition; another sample (45.3 $\mathrm{m} \mathrm{b.g.1.)} \mathrm{was} \mathrm{picked} \mathrm{from} \mathrm{the}$ centre of the slope, close to the shear band of the main landslide (P2: Figures $8 \mathrm{a}$ and $9 \mathrm{~b})$. The shallowest sample (21.6 m b.g.1.) was collected a few meters out of the main landslide body, NE of the head, where the rocky portion starts becoming more abundant in the FAE unit (P3: Figures $8 \mathrm{a}$ and $9 \mathrm{~b})$. In all cases, the clay minerals were abundant (77-82\% in the total sample, $82-90 \%$ in the clay fraction), followed by small amounts of quartz, calcite and feldspar. Among the clay minerals, smectite was largely predominant (53-68\% in the fraction smaller than $2 \mu \mathrm{m}$, with the largest value belonging to the shallowest sample), followed by illite and kaolinite, which explains the poor intrinsic mechanical properties observed for the soil portion of FAE, as discussed below.

Classification through the Standard Plasticity Chart [53], shown in Figure 14, demonstrates that FAE may include clay layers, often quoted as marly in the literature (see e.g., [54]), despite not being cemented, which can rather be classified as high plasticity clays or silts. The FAE at Bovino by far included the clay layers of highest plasticity, with the clays from the centre of the slope ranging from high to extremely high plasticity clays $(\mathrm{CH}$, $\mathrm{CV}, \mathrm{CE}$ in Figure 14). As calcarenite became more abundant, as in FAE $\mathrm{C}_{\mathrm{C}}$, the corresponding soil samples were tended to be classified as silts, of intermediate to very high plasticity (MI, $\mathrm{MH}, \mathrm{MV})$. With regard to the other sites, samples from the clayey $\mathrm{FAE}_{\mathrm{A}}$ were classified as $\mathrm{CH}$, while those sampled within $\mathrm{FAE}_{\mathrm{C}}$ plot in the $\mathrm{CI}$ interval, with the sole exception of 
one datapoint referring to a sample taken within $\mathrm{FAE}_{\mathrm{C}}$ at Volturino, which plotted at the upper bound of the $\mathrm{CH}$ band.
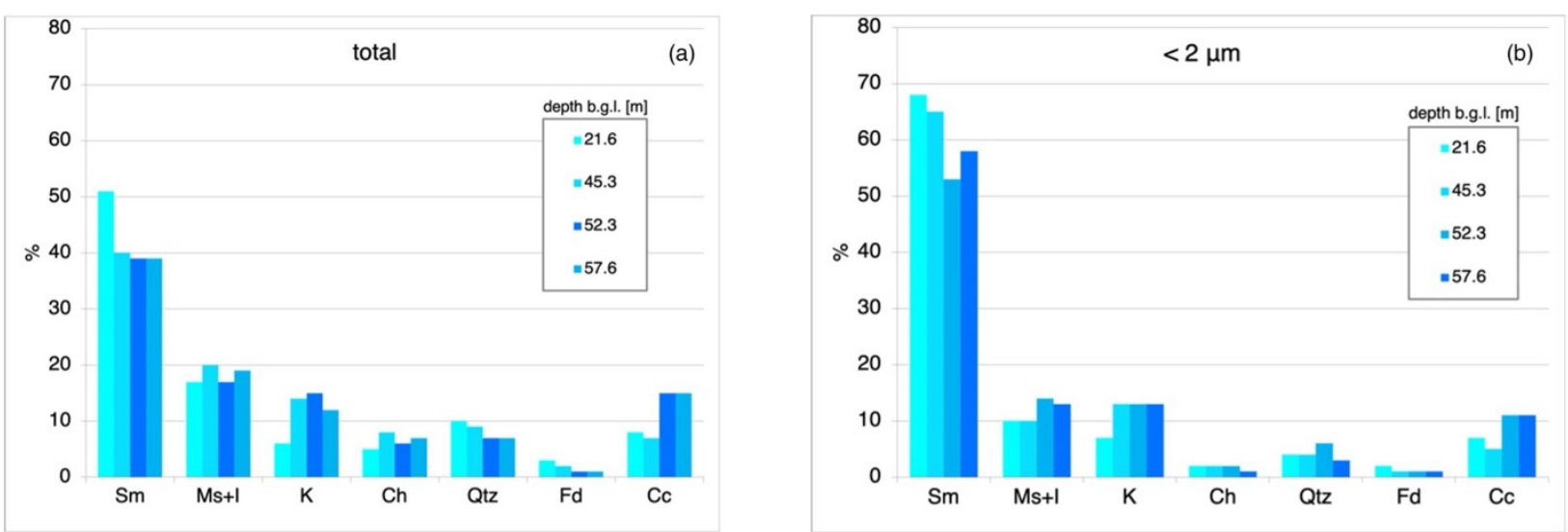

Figure 13. X-ray diffractometry on clayey Faeto Flysch samples from Bovino: (a) total sample; (b) clay fraction.

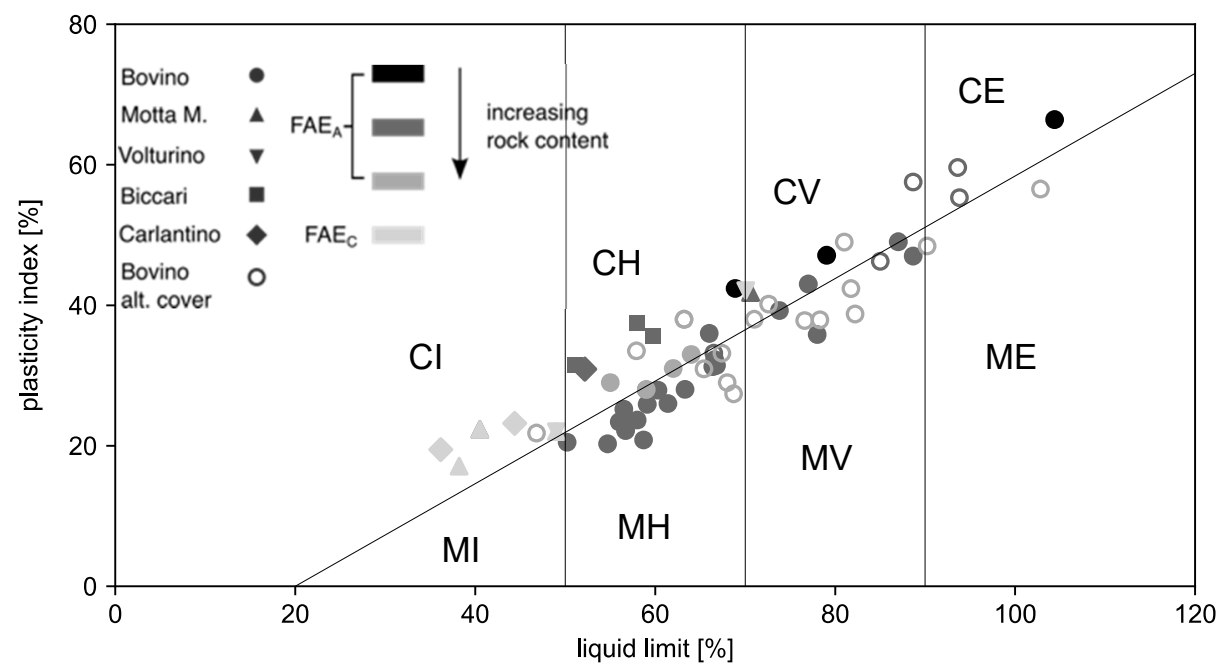

Figure 14. Classification of Faeto Flysch: standard plasticity chart [53].

Being mostly classified at least as highly plastic, either $\mathrm{CH}$ or $\mathrm{MH}$-and in some cases up to extremely plastic - the soil matrix of FAE, even where rock layers and inclusions are more frequent and persistent, was expected to exhibit low values of shear strength parameters, as shown below in this section. If combined with the high piezometric levels found in the slopes of reference, the resulting available shear strength was found to be particularly low. Thus, the soil matrix is expected to govern the onset and progression of failure and, as such, represents an internal predisposing factor to the instability of the slopes. This contrasts with the FAE being often described as a mostly marly or calcareous material in the traditional geological literature (e.g., [41,54]), thus implicitly leading one to assume better mechanical properties for the material with respect to what was found in this study.

The profiles of the index properties with depth are plotted in Figure 15a-c. Although rather dispersed, due to the inherent heterogeneity of the material, inspection of the plots reveals some common trends. The clay fraction (CF, Figure 15a) was recurrently found to increase with depth, as shown here for the representative pilot sites, with the lowest values generally applying to the shallow $\mathrm{FAE}_{\mathrm{C}}$ (e.g., at Motta Montecorvino: $12 \%$ at $1.5 \mathrm{~m}$ b.g.l.) and the highest ones at great depth (e.g., in the centre of Pianello slope at Bovino: 66\% at $45.0 \mathrm{~m}$ b.g.1.). A high CF, up to $73 \%$, was also found for shallow $\mathrm{FAE}_{\mathrm{A}}$ samples at Volturino and Motta Montecorvino. The samples from the altered cover at Bovino included 
a CF larger on average than those collected elsewhere at comparable depths, although the shallowest sample from the more calcareous portions showed more erratic values. The plasticity index (PI) (Figure 15b), ranging from $19 \%$ for the $\mathrm{FAE}_{\mathrm{C}}$ at Motta Montecorvino to $65 \%$ for deep $\mathrm{FAE}_{\mathrm{A}}$ samples at Bovino, followed a very similar trend to the $\mathrm{CF}$ at all sites. As far as the activity (A) of the clay fraction is concerned (Figure 15c), the values appeared scattered in the interval $0.45-1.55$, hence spanning the whole range of low to high activity. Interestingly, Biccari hosts the $\mathrm{FAE}_{\mathrm{A}}$ with the most active clay; the lowest $\mathrm{A}$ values were recorded at Carlantino. At Bovino, the highest A, close to 1.0, was obtained for the samples from the more clay-rich part of $\mathrm{FAE}_{\mathrm{A}}$, i.e., at depth in the centre of the slope, and for the overlying altered $\mathrm{FAE}_{\mathrm{A}, \mathrm{W}}$ cover.
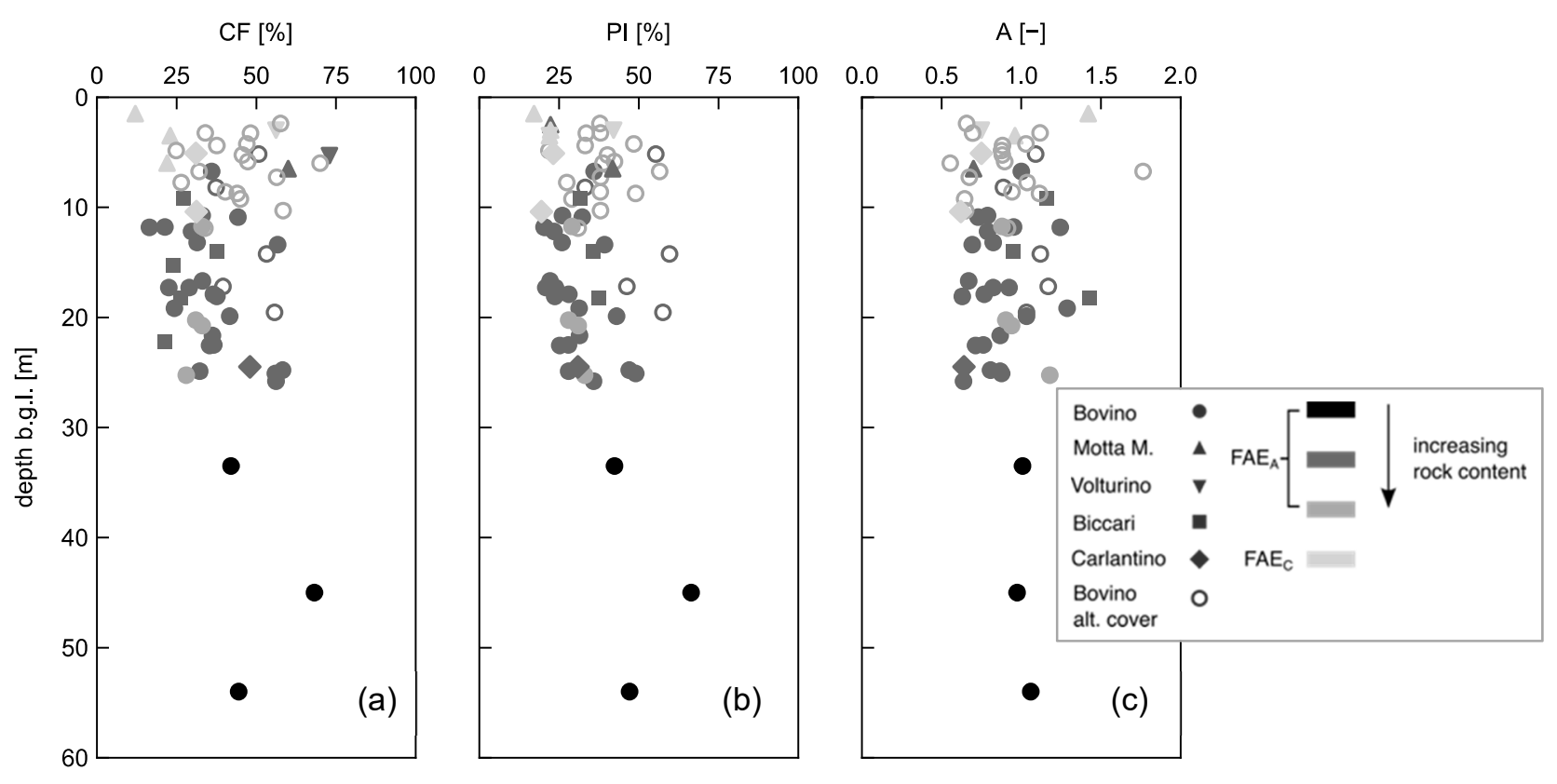

Figure 15. Index properties of Faeto Flysch: clay fraction (a); plasticity index (b); activity (c).

The profiles of physical and state properties with depth, in particular unit weight $\gamma$ and void ratio $e$ (Figure 16a,b), are also indicative of the extreme variability of the FAE. The $\gamma$ (mostly of saturated samples) was lowest at Bovino, with values as low as $16.5 \mathrm{kN} / \mathrm{m}^{3}$, decreasing with depth, and was very scattered for the shallow samples belonging to the altered cover farther from the centre of the Pianello slope, where the underlying FAE substratum was more calcareous, with one sample hitting a low at $15.6 \mathrm{kN} / \mathrm{m}^{3}$. The highest $\gamma$, approximately $21.5 \mathrm{kN} / \mathrm{m}^{3}$ maximum, was measured at Biccari and Carlantino. Consistently, the profiles of $e$ with depth were also quite dispersed across the various sites, and were the highest at Bovino, reaching 1.245 in the $\mathrm{FAE}_{\mathrm{A}}$ at great depth, and 1.643-1.777 for two shallow samples of the altered cover. Similarly, values of $e$ for the other sites spanned the range of 0.39-0.91, with average values at Biccari and Carlantino being closer to the lower bound of the interval.

It is somewhat more difficult to identify a clear trend for the consistency index (CI) (calculated from the fully saturated water content), whose profile with depth is depicted in Figure 16c. With the sole exception of Bovino, the few available data of $24.5 \mathrm{~m}$ depth ranged in the wide interval of $0.68-1.28$ and seemed to suggest an increase of $\mathrm{CI}$ with depth. For Bovino, instead, the average CI was quite constantly close to 1.0 down to $25.0 \mathrm{~m}$ depth, and consistently lower than 0.93 , and decreasing, at great depth. This evidence is strongly related to landslide-induced remoulding, as the soil collected at depth at Bovino has undergone significant dilation due to shearing along the shear bands. 

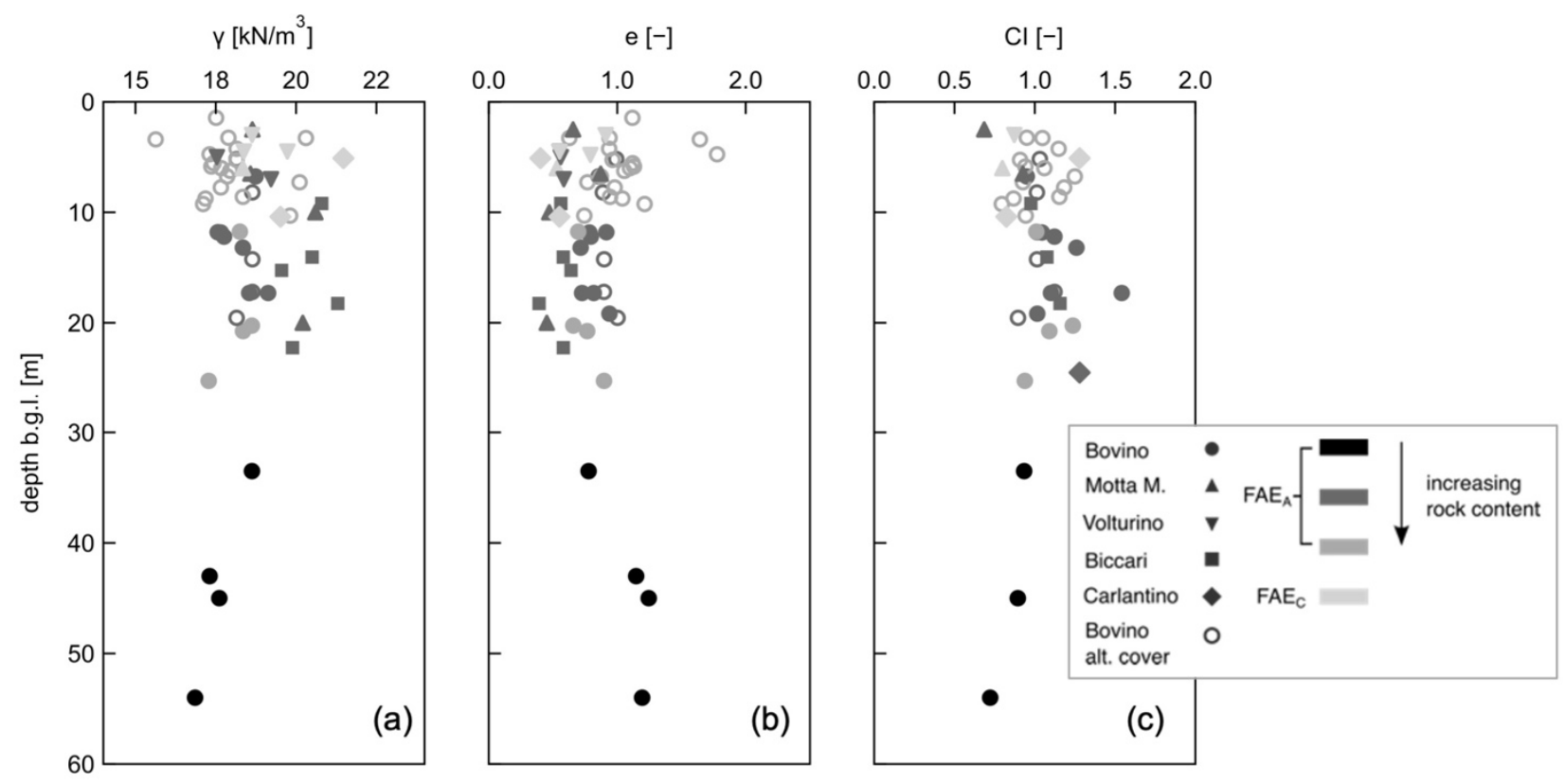

Figure 16. Physical and state properties of Faeto Flysch: total unit weight (a); void ratio (b), consistency index (c).

Figure 17 shows three compression curves from oedometer tests performed on samples collected at Bovino. Two deep samples were collected in the most clayey part of the $\mathrm{FAE}_{\mathrm{A}}$ from the centre of the slope (Figure 8a,b), one of them (P2-C3, $45.0 \mathrm{~m}$ b.g.1.) in the disturbed zone very close to the shear band identified through inclinometer I2 (Figure 9a,b). A shallower sample (P3-C1, 6.0 m b.g.l.) was picked just outside of landslide body A (Figures $8 \mathrm{a}$ and $9 \mathrm{~b}$ ), where rocky layers are more abundant, in the altered cover of FAE. In all three tests, the applied vertical effective stress $\sigma^{\prime}{ }_{\mathrm{v}}$ appeared to have reached the yield stress, indicated by an arrow in the plot; for each sample, the in situ state is indicated by an isolated point.

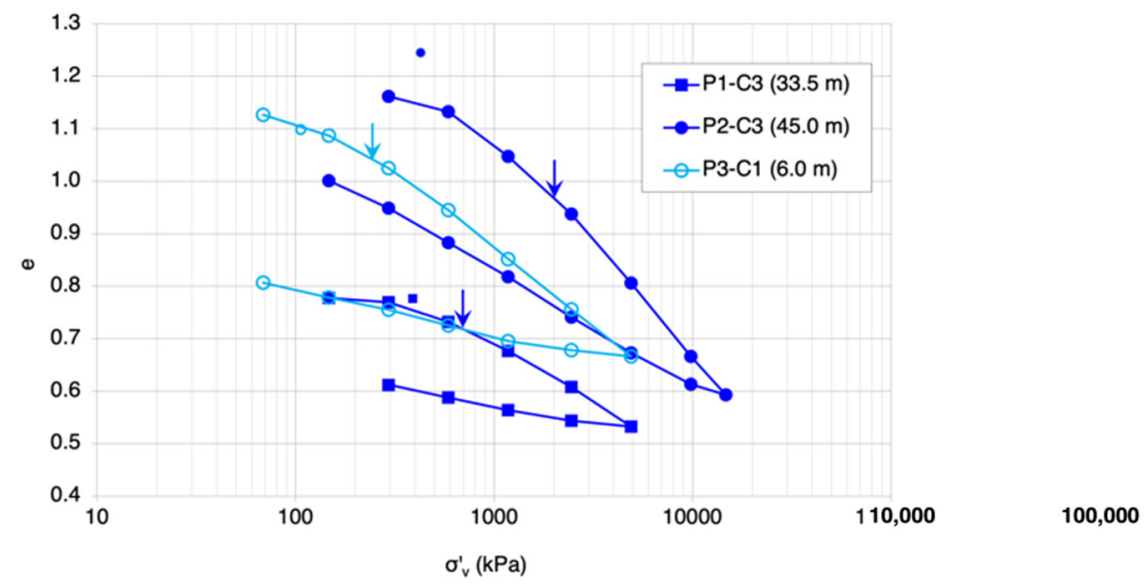

Figure 17. Sample oedometric compression curves for Faeto Flysch at Bovino; isolated points indicate the in situ state.

Samples P1-C3 and P3-C1 exhibited comparable yield stress ratios (YSRs), compression index $\left(\mathrm{C}_{\mathrm{C}}\right)$ and swelling index $\left(\mathrm{C}_{\mathrm{S}}\right)\left(\mathrm{P} 1-\mathrm{C} 3\right.$ : $\mathrm{YSR}=1.8, \mathrm{C}_{\mathrm{C}}=0.251, \mathrm{C}_{\mathrm{S}}=0.065$; P2-C3: $\left.\mathrm{YSR}=2.15, \mathrm{C}_{\mathrm{C}}=0.298, \mathrm{C}_{\mathrm{S}}=0.077\right)$. Sample P2-C3, instead, showed significantly higher values of the same parameters $\left(Y S R=2.59, C_{C}=0.406, C_{S}=0.204\right)$. In addition to having a high CF and being the most plastic of all samples (CF $=68 \%, \mathrm{PI}=66 \%$ ), the disturbance induced by intense shearing and consequent dilation in the shear band, testified also by the high initial void ratio of the sample, justify the high $C_{C}$ exhibited by this sample. 
The same applies to the exceptionally high $\mathrm{C}_{S}$, which possibly also suffers from further destructuration induced by compression up to $\sigma^{\prime}{ }_{\mathrm{V}}=15 \mathrm{MPa}$ in a high pressure oedometer. Figure 18a,b shows the Mohr-Coulomb peak failure envelopes for all sites, for $F_{A E}$ and $\mathrm{FAE}_{\mathrm{A}}$, respectively, as deduced from both direct shear and triaxial tests. For both $\mathrm{FAE}_{\mathrm{C}}$ and $\mathrm{FAE}_{\mathrm{A}}$, the shaded areas in the figures highlight the extent of the strength domains, for both the low and the high confining stress range, where the material exhibits $d r y$ and wet behaviour, respectively, as defined in Critical State Soil Mechanics [55].

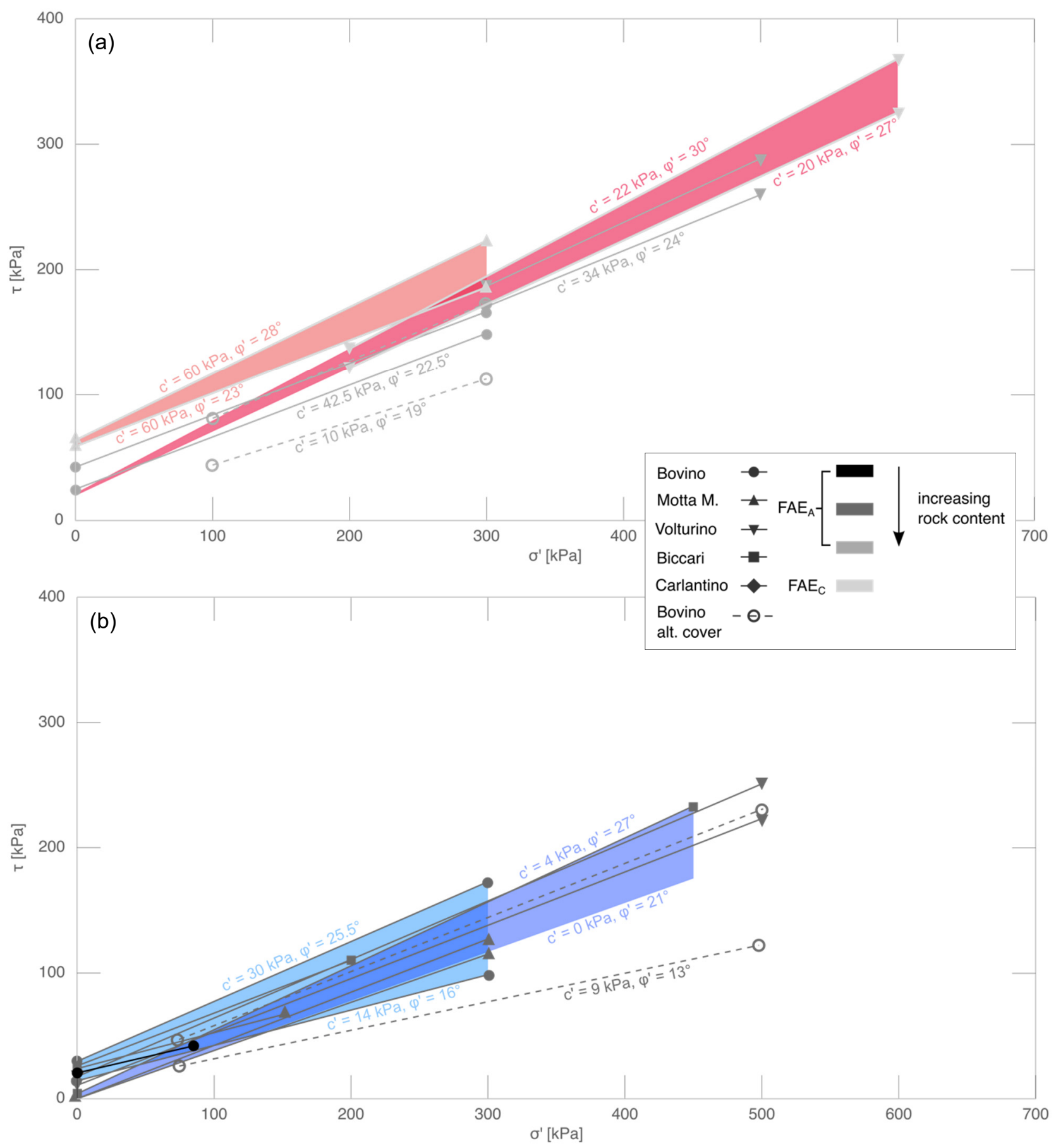

Figure 18. Mohr-Coulomb peak shear strength envelopes: (a) rocky; (b) clayey Faeto Flysch.

In general, as expected, samples from the $\mathrm{FAE}_{\mathrm{C}}$ (Figure 18a) corresponded to higher strength with respect to the $\mathrm{FAE}_{\mathrm{A}}$. The peak failure envelopes for $\mathrm{FAE}_{\mathrm{C}}$ varied in the range $\left(\mathrm{c}^{\prime}=60 \mathrm{kPa}, \varphi^{\prime}=23^{\circ}\right)-\left(\mathrm{c}^{\prime}=60 \mathrm{kPa}, \varphi^{\prime}=28^{\circ}\right)$, measured in the low-stress range at Motta Mon- 
tecorvino, to $\left(\mathrm{c}^{\prime}=20 \mathrm{kPa}, \varphi^{\prime}=27^{\circ}\right)-\left(\mathrm{c}^{\prime}=22 \mathrm{kPa}, \varphi^{\prime}=30^{\circ}\right)$ at Volturino, for higher confining stress. In the same figure, samples from a transitional $\mathrm{FAE}_{\mathrm{C}}-\mathrm{FAE}_{\mathrm{A}}$ portion of $\mathrm{FAE}$ collected at Volturino, fell right below the range, yielding $\left(\mathrm{c}^{\prime}=37 \mathrm{kPa}, \varphi^{\prime}=27^{\circ}\right)-\left(\mathrm{c}^{\prime}=34 \mathrm{kPa}, \varphi^{\prime}=24^{\circ}\right)$. For sake of comparison, the strength envelopes for the $\mathrm{FAE}_{\mathrm{A}}$ richest in calcareous inclusions at Bovino, i.e., towards the borders of the Pianello slope, are also plotted in Figure 18a. They bracket the relatively narrow region from $\left(\mathrm{c}^{\prime}=25 \mathrm{kPa}, \varphi^{\prime}=22.5^{\circ}\right)$ to $\left(c^{\prime}=42.5 \mathrm{kPa}, \varphi^{\prime}=22.5^{\circ}\right)$, right beyond the lower bound of the region for the $\mathrm{FAE}_{\mathrm{C}}$, thus suggesting a gradual transition between the responses of $\mathrm{FAE}_{\mathrm{A}}$ and $F A E_{C}$. In the same area of Bovino, samples from the most calcarenite rich part of the altered cover, $\mathrm{FAE}_{\mathrm{A}, \mathrm{W}}$, exhibited a significant drop in the lower bound of the strength envelopes with respect to the deeper unaltered substratum, as low as $\left(\mathrm{c}^{\prime}=10 \mathrm{kPa}, \varphi^{\prime}=19^{\circ}\right)$.

Consistent with the heterogeneity of the material, the failure envelopes for $\mathrm{FAE}_{\mathrm{A}}$ (Figure $18 \mathrm{~b}$ ) at $\sigma^{\prime}<300 \mathrm{kPa}$, lie in a relatively wide fan, mainly inferred from samples collected in the centre of the Pianello slope at Bovino, with boundaries $\left(\mathrm{c}^{\prime}=14 \mathrm{kPa}\right.$, $\left.\varphi^{\prime}=16^{\circ}\right)-\left(\mathrm{c}^{\prime}=30 \mathrm{kPa}, \varphi^{\prime}=25.5^{\circ}\right)$. Samples of $\mathrm{FAE}_{\mathrm{A}}$, exhibiting wet behaviour at larger confining stress [53], spanned the region bounded by $\left(\mathrm{c}^{\prime}=4 \mathrm{kPa}, \varphi^{\prime}=27^{\circ}\right)-\left(\mathrm{c}^{\prime}=0, \varphi^{\prime}=21^{\circ}\right)$, with the lowest strength measured at Motta Montecorvino and the highest at Biccari, consistent with the larger sand content (Figure 12) and relatively lower plasticity (Figure 14) of samples from the latter with respect to other sites. One sample of FAE $\mathrm{A}_{\mathrm{A}}$ with the highest clay content, collected from $45.0 \mathrm{~m}$ b.g.l. at Bovino (P2-C3), exhibited a plummet of shear strength with respect to the other samples from the same unit, with values of the strength parameters as low as $\left(c^{\prime}=21.3 \mathrm{kPa}, \varphi^{\prime}=13.7^{\circ}\right)$, as an effect of dilation and shearing in the proximity of the shear band of the landslide (Figure 9b), as discussed below. Results for the altered cover of the most clayey $\mathrm{FAE}_{\mathrm{A}}$, in the centre of the Pianello slope (Figure 18b), resemble those obtained for the parent substratum, although varying in a wider range, implying more heterogeneity, and with significantly lower mean values, as an effect of soil weathering: $\left(c^{\prime}=9 \mathrm{kPa}, \varphi^{\prime}=13^{\circ}\right)-\left(\mathrm{c}^{\prime}=25 \mathrm{kPa}, \varphi^{\prime}=23^{\circ}\right)$.

The average poor shear strength inferred from Figure 18 for the soil layers of FAE sampled at the reference sites, regardless of their rock content, was consistent with the high measured CF and PI (Figure 15a,b), the latter in turn strongly related to the high smectitic content of the clayey fraction, particularly for the samples of $\mathrm{FAE}_{\mathrm{A}}$ and $\mathrm{FAE}_{\mathrm{A}, \mathrm{W}}$ from the centre of the Pianello landslide at Bovino.

Figure 19 shows the stress paths of CIU triaxial tests on two samples collected at Bovino (P2-C3 at $45.0 \mathrm{~m}$ b.g.1. and P3-C1 at $6.0 \mathrm{~m}$ b.g.1.), whose oedometric compression curves are shown in Figure 17, which highlight the effect of soil disturbance due to shearing in the shear band zone. In fact, the state boundary surface (SBS) of the deeper sample, sketched in the figure, only available on the dry side [55], seems to be closely comparable in size to that inferred from the shallower one, picked in the altered cover on the outskirts of the Pianello slope. This evidence supports the hypothesis that remoulding of the deep sample due to landsliding has negatively impacted its overall mechanical properties, as suggested earlier. The resulting peak strength parameters were $\left(\mathrm{c}^{\prime}=21 \mathrm{kPa}, \varphi^{\prime}=13.7^{\circ}\right)$ for sample P2-C3 and $\left(\mathrm{c}^{\prime}=8 \mathrm{kPa}, \varphi^{\prime}=13.2^{\circ}\right)$ for P3-C1. Worth noting as well are the remarkably low values of friction angles at the critical states inferred for the deep $\left(\varphi^{\prime} \mathrm{CS}=22^{\circ}\right)$ and shallow sample $\left(\varphi^{\prime} \mathrm{CS}=15.6^{\circ}\right)$, consistent with the high $\mathrm{CF}$, its mineralogical composition, and consequently high PI: $(\mathrm{CF}=70 \%, \mathrm{PI}=39 \%)$ and $(\mathrm{CF}=68 \%, \mathrm{PI}=66 \%)$, respectively.

Finally, the evaluation of the residual shear strength on two FAE specimens from Motta Montecorvino, with the direct shear box, and from Bovino, with the Bromhead ring shear apparatus, yielded very low values of the residual angle of friction, namely $\varphi_{\mathrm{r}}{ }^{\prime}=8^{\circ}$ and $\varphi_{\mathrm{r}}{ }^{\prime}=8.7^{\circ}$, respectively, again fitting in the same picture of a material with high PI and $\mathrm{CF}$, predominantly composed of smectite.

At all sites, the permeability $k$ of the FAE samples, evaluated through oedometer tests or constant head permeameter, fell in the range of $10^{-11}-10^{-10} \mathrm{~m} / \mathrm{s}$. Even assuming $k$ one order of magnitude larger than calculated in laboratory tests, as commonly done, these values seem to grossly underestimate the actual permeability exhibited by the FAE at the 
scale of the slope, which is likely to be heavily influenced by the presence of fractured rock interlayers and inclusions, in different proportions both in the $\mathrm{FAE}_{\mathrm{A}}$ and in the $\mathrm{FAE}_{\mathrm{C}}$. This is undoubtedly suggested by phenomenological evidence: intense groundwater flow observed through the FAE at many sites, high hydraulic heads measured down to great depth and reactivation of the landslides due to the seasonal rainfall. It is also corroborated by the results of numerical analyses (e.g., $[23,24,52,56]$ ) and field tests. In fact, water infiltration tests performed with a Guelph pressure infiltrometer at Volturino returned $k=5.0 \times 10^{-6} \mathrm{~m} / \mathrm{s}$ and $k=5.0 \times 10^{-8} \mathrm{~m} / \mathrm{s}$ for $\mathrm{FAE}_{\mathrm{C}}$ and $\mathrm{FAE}_{\mathrm{A}}$, respectively [57].

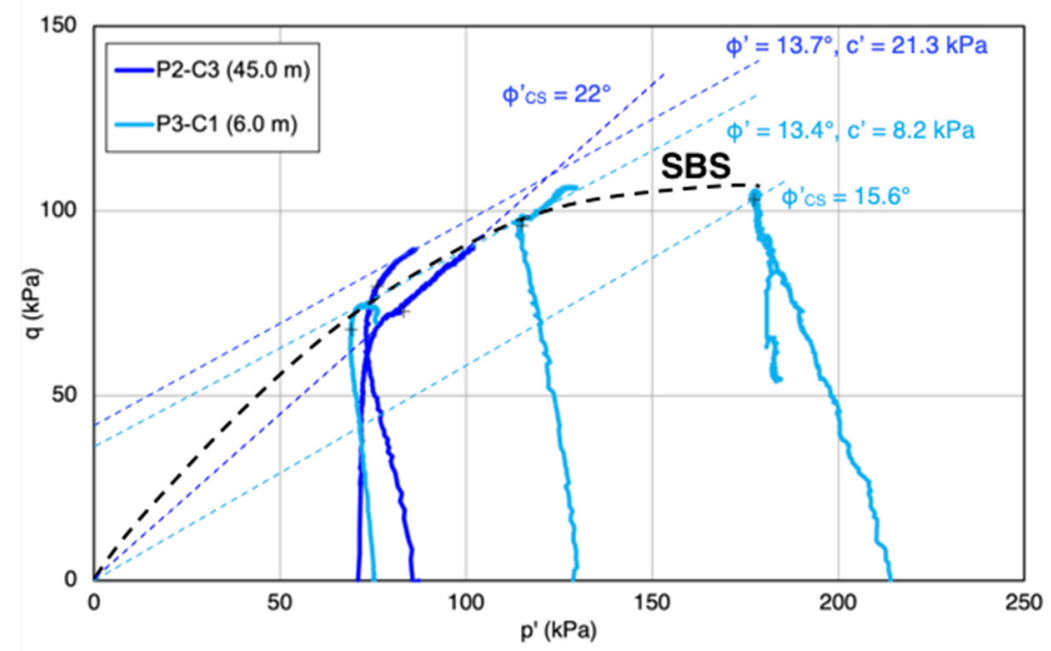

Figure 19. CIU triaxial stress-paths for deep clayey Faeto Flysch (borehole P2-C3, $45 \mathrm{~m}$ b.g.l.) and shallow altered cover of the same formation (P3-C1, $6 \mathrm{~m}$ b.g.1.) at Bovino.

\section{Discussion and Conclusions}

The results presented in this paper highlight the remarkable variability of the geotechnical properties of Faeto Flysch, not only among the different sites but also across a single slope. Such variability is either intrinsic, due to the lithological heterogeneity of the units in the formation, with varying proportions of clay and rock, often fractured, either layered or embedded as disarranged masses, or has been induced by a varying degree of tectonic disturbance [58] and previous landsliding. The analytic comparison of the geotechnical properties and monitoring data, as well as the analysis of the slope processes at the pilot sites, allowed the recurrent features of the Faeto Flysch to be identified that cause such a formation to be recurrently involved in landsliding. In particular, the flysch features representing predisposing factors of slope instability have been identified and found to recur at the different sites.

In particular, it is found that, mainly due to its mineralogical composition, showing an outstanding smectite content, the soil portion of the FAE units is endowed with a dominant fines fraction of high plasticity and activity indices. These, in turn, entail remarkably low intrinsic strength properties, with critical state friction angles as low as $16^{\circ}$, and residual ones of $8^{\circ}$. Such a feeble shear strength implies that the soil portion of this turbidite governs the onset of instability, regardless of the rock/soil ratio of the FAE units found in the slope.

In some cases, e.g., for the pilot test site of Bovino, where samples were collected down to great depth, the profiles of CF, PI, A and $e$ give evidence to values that tend to increase with depth, while CI decreases. This peculiar distribution of soil index and state properties, and the consequent values of shear strength parameters, tend to favour the onset of deep failure and hence give rise to slow (max displacement rate approximately $40 \mathrm{~mm}$ /year), deep-seated landslide bodies, such as those observed at Bovino and Motta Montecorvino. Furthermore, the plummet in shear strength from peak to residual, as observed in samples from the same two sites, renders pre-existing shear bands, where post-peak strength parameters are mobilised, prone to reactivation and retrogression, even for small triggering perturbations of the applied loads and boundary conditions. 
Another peculiar trait of the FAE is the large slope-scale permeability, due to the presence of rock portions with persistent fractures throughout the thickness of the deposit, both in $\mathrm{FAE}_{\mathrm{C}}$ and in $\mathrm{FAE}_{\mathrm{A}}$ units. The presence of fractures facilitates rainfall infiltration into the slope, hence inducing high piezometric levels down to very great depths-a predisposing factor to instability - and allows for seasonal oscillation of such levels, thus triggering reactivation even for deep-seated landslides. This applies also if the FAE is not directly involved in the failure; in fact, as in the case at Fontana Monte in Volturino, intense flow through preferential seepage paths may take place in the rocky $\mathrm{FAE}_{\mathrm{C}}$ and provide a severe hydraulic boundary condition for the adjacent fine-grained material, in which landsliding eventually takes place [59].

The paper provides a qualitative interpretation connecting the geo-hydro-mechanical features shared by many turbiditic formations in various areas of the world to the observed instability of their slopes. Improving the understanding of the role of those geomaterials in the landslide processes-such as is the case for the Faeto Flysch in the Daunia Apennines discussed in this paper-is a key step towards the identification of the most suitable landslide mitigation measures for safeguarding and unlocking the development of many biased inner areas rising in similar geological contexts. As in many of the examined cases, the high piezometric levels are a crucial predisposing factor for the instability, and the currently observed activity appears to be triggered by seasonal increases of such levels due to rainfall infiltration; it is reasonable that any structural intervention for landslide stabilisation - which should in any case account for the great depth of the main landslide bodies-should be implemented in combination with measures for controlling pore water pressures in the slope. Finally, by providing ranges of variability of shear strength parameters and slope-scale permeability, the results shown in this paper may be valuable for advanced numerical modelling of the landslide processes taking place in slopes of clay-dominated flysch formations of similar composition.

Author Contributions: Conceptualization, N.L. and F.C.; methodology, F.C.; investigation, N.L., F.S., F.C., C.V. and O.B.; data curation, N.L. and C.V.; writing-original draft preparation, N.L. and F.S.; writing - review and editing, N.L., F.C., F.S. and C.V.; visualization, N.L. and F.S.; supervision, F.C.; funding acquisition, F.C., N.L. and O.B. All authors have read and agreed to the published version of the manuscript.

Funding: The research is funded by the European Social Fund (ESF), through the National Operational Program Research and Innovation 2014-2020 "Attraction and International Mobility" (PONAIM project code AIM1871082), and by the Governmental Commissary for Hydrological Risk of the Apulia Region, through two Research Agreements: "Inquadramento di primo livello degli assetti geomeccanici, sulla base dei dati esistenti, dell'area in cui si insedia il Lago Pescara, e costruzione di un modello concettuale della circolazione idrica superficiale e sotterranea della suddetta area nel territorio di Biccari (FG)" and "Caratterizzazione geomeccanica di I livello del settore meridionale del centro abitato di Biccari (FG)".

Institutional Review Board Statement: Not applicable.

Informed Consent Statement: Not applicable.

Data Availability Statement: Not applicable.

Conflicts of Interest: The authors declare no conflict of interest.

\section{References}

1. Cruden, D.; Varnes, D. Chapter 3-Landslides Types and Processes. In Landslides: Investigation and Mitigation; Transportation Research Board: Washington, DC, USA, 1996.

2. Cotecchia, F.; Santaloia, F.; Lollino, P.; Vitone, C.; Mitaritonna, G. Deterministic Landslide Hazard Assessment at Regional Scale. In Proceedings of the GeoFlorida 2010: Advances in Analysis, Modeling \& Design, Orlando, FL, USA, 20-24 February 2010; pp. 3130-3139.

3. Terzaghi, K. Mechanism of Landslides. In Application of Geology to Engineering Practice; Paige, S., Ed.; Geological Society of America: Boulder, CO, USA, 1950. 
4. Croce, A. Opening adress. In Proceedings of the International Symposium: The Geotechnics of Structurally Complex Formations, Capri, Italy, 19-21 September 1977; Volume II, pp. 148-151.

5. Fenelli, G.; Paparo Filomarino, M.; Picarelli, L.; Rippa, F. Proprietà Fisiche e Meccaniche Di Argille Varicolori Dell'Irpinia. Riv. Ital. Geotec. 1982, 3, 110-124.

6. Pellegrino, A.; Picarelli, L. Contributo Alla Caratterizzazione Geotecnica Di Formazioni Argillose Intensamente Tetonizzate. Geol. Appl. E Idrogeol. 1985, 20, 155-192.

7. Santaloia, F.; Cotecchia, F.; Polemio, M. Mechanics of a Tectonized Soil Slope: Influence of Boundary Conditions and Rainfall. Q. J. Eng. Geol. Hydrogeol. 2001, 34, 165-185. [CrossRef]

8. Cotecchia, F.; Santaloia, F.; Vitone, C.; Cafaro, F. The mechanical behaviour of intensely fissured high plasticity clays from Daunia. In Characterisation and Engineering Properties of Natural Soils; Phoon, K., Hight, D., Leroueil, S., Tan, T., Eds.; CRC Press: London, UK, 2007.

9. Cotecchia, F.; Vitone, C.; Santaloia, F.; Pedone, G.; Bottiglieri, O. Slope Instability Processes in Intensely Fissured Clays: Case Histories in the Southern Apennines. Landslides 2015, 12, 877-893. [CrossRef]

10. Silvestri, F.; Vitone, C.; d'Onofrio, A.; Cotecchia, F.; Puglia, R.; de Magistris, F. The influence of meso-structure on the mechanical behaviour of a marly clay from low to high strains. In Soil Stress-Strain Behavior: Measurement, Modeling and Analysis; Springer: Heidelberg, Germany, 2007; pp. 333-350.

11. Nardelli, V.; Coop, M.; Vitone, C.; Chen, S. The Inter-Scale Behaviour of Two Natural Scaly Clays. Géotech. Lett. 2016, 6, 205-210. [CrossRef]

12. Vitone, C.; Cotecchia, F.; Federico, A.; Viggiani, G. On the Geomechanical Characterisation of Complexities in Clays: Experimental Studies. Riv. Ital. Geotec. 2018, 2, 1-29.

13. Vitone, C.; Guglielmi, S.; Pedone, G.; Cotecchia, F. Effects of Micro- to Meso-Features on the Permeability of Fissured Clays. Géotechnique Lett. 2019, 9, 369-376. [CrossRef]

14. Cotecchia, F.; Pedone, G.; Bottiglieri, O.; Santaloia, F.; Vitone, C. Slope-Atmosphere Interaction in a Tectonized Clayey Slope: A Case Study. Riv. Ital. Geotec. 2014, 1, 28.

15. Cotecchia, F.; Petti, R.; Milella, D.; Lollino, P. Design of Medium Depth Drainage Trench Systems for the Mitigation of Deep Landsliding. Geosciences 2020, 10, 174. [CrossRef]

16. Cotecchia, F.; Santaloia, F.; Tagarelli, V. Towards A Geo-Hydro-Mechanical Characterization of Landslide Classes: Preliminary Results. Appl. Sci. 2020, 10, 7960. [CrossRef]

17. Palmisano, F.; Vitone, C.; Cotecchia, F. Methodology for Landslide Damage Assessment. Procedia Eng. 2016, 161, 511-515. [CrossRef]

18. Palmisano, F.; Vitone, C.; Cotecchia, F. Assessment of Landslide Damage to Buildings at the Urban Scale. J. Perform. Constr. Facil. 2018, 32, 04018055. [CrossRef]

19. Tagarelli, V.; Cotecchia, F. Deep Movements in Clayey Slopes Relating to Climate: Modeling for Early Warning System Design. In Proceedings of the Geotechnical Research for Land Protection and Development; Calvetti, F., Cotecchia, F., Galli, A., Jommi, C., Eds.; Springer International Publishing: Cham, Switzerland, 2020; pp. 205-214.

20. Cotecchia, F.; Tagarelli, V.; Pedone, G.; Ruggieri, G.; Guglielmi, S.; Santaloia, F. Analysis of Climate-Driven Processes in Clayey Slopes for Early Warning System Design. Proc. Inst. Civ. Eng. Geotech. Eng. 2019, 172, 465-480. [CrossRef]

21. Tagarelli, V.; Cotecchia, F. The Effects of Slope Initialization on the Numerical Model Predictions of the Slope-VegetationAtmosphere Interaction. Geosciences 2020, 10, 85. [CrossRef]

22. Cotecchia, F.; Santaloia, F.; Lollino, P.; Vitone, C.; Pedone, G.; Bottiglieri, O. From a Phenomenological to a Geomechanical Approach to Landslide Hazard Analysis. Eur. J. Environ. Civ. Eng. 2016, 20, 1004-1031. [CrossRef]

23. Lollino, P.; Cotecchia, F.; Elia, G.; Mitaritonna, G.; Santaloia, F. Interpretation of Landslide Mechanisms Based on Numerical Modelling: Two Case-Histories. Eur. J. Environ. Civ. Eng. 2016, 20, 1032-1053. [CrossRef]

24. Elia, G.; Cotecchia, F.; Pedone, G.; Vaunat, J.; Vardon, P.J.; Pereira, C.; Springman, S.M.; Rouainia, M.; Van Esch, J.; Koda, E.; et al. Numerical Modelling of Slope-Vegetation-Atmosphere Interaction: An Overview. Q. J. Eng. Geol. Hydrogeol. 2017, 50, 249-270. [CrossRef]

25. Cotecchia, F.; Santaloia, F.; Pedone, G.; Vitone, C.; Lollino, P.; Mitaritonna, G. Diagnosis of Slow Landslides Affecting Tectonised Clayey Slopes (Southern Apennines). In Engineering Geology for Society and Territory; Lollino, G., Giordan, D., Crosta, G.B., Corominas, J., Azzam, R., Wasowski, J., Sciarra, N., Eds.; Springer International Publishing: Cham, Switzerland, 2015; Volume 2, pp. 1029-1032.

26. Melidoro, A.; Melidoro, G.; Panaro, V. Deformazioni Gravitative Dei Versanti Nei Terreni Flisciodi Con Argille a Bentoniti Di Santa Croce Di Magliano (Molise). Quarry Constr. 2002, 2, 11-17.

27. Giordan, D.; Allasia, P.; Manconi, A.; Baldo, M.; Santangelo, M.; Cardinali, M.; Corazza, A.; Albanese, V.; Lollino, G.; Guzzetti, F. Morphological and Kinematic Evolution of a Large Earthflow: The Montaguto Landslide, Southern Italy. Geomorphology 2013, 187, 61-79. [CrossRef]

28. Lollino, P.; Giordan, D.; Allasia, P. The Montaguto Earthflow: A Back-Analysis of the Process of Landslide Propagation. Eng. Geol. 2014, 170, 66-79. [CrossRef] 
29. Lollino, P.; Giordan, D.; Allasia, P.; Pastor, M. Analysis of the Propagation of a Large Earthflow by SPH Technique Application. In Proceedings of the 12th International Symposium on Landslides and Engineered Slopes, Experience, Theory and Practice, Napoli, Italy, 12-19 June 2016; Volume 2, pp. 1313-1321.

30. Lollino, P.; Giordan, D.; Allasia, P.; Fazio, N.L.; Perrotti, M.; Cafaro, F. Assessment of Post-Failure Evolution of a Large Earthflow through Field Monitoring and Numerical Modelling. Landslides 2020, 17, 2013-2026. [CrossRef]

31. Cotecchia, V.; Del Prete, M.; Federico, A.; Fenelli, G.; Pellegrino, A.; Picarelli, L. Studio Di Una Colata Attiva in Formazioni Strutturalmente Complesse Presso Brindisi Di Montagna Scalo (PZ). AGI-XVI Conv. Naz. Geotec. 1986, $253-264$.

32. Picarelli, L. Modellazione e Monitoraggio Di Una Colata in Formazioni Strutturalmente Complesse. In Proceedings of the Convegno su Cartografia e Monitoraggio dei Movimenti Franosi, Bologna, Italy, 10-11 November 1988; pp. 119-130.

33. Bentivenga, M.; Grimaldi, S.; Palladino, G. Caratteri Geomorfologici Della Instabilità Del Versante Sinistro Del Fiume Basento Interessato Dalla Grande Frana Di Brindisi Di Montagna Scalo (Potenza, Basilicata). G. Geol. Appl. 2006, 4, $123-130$.

34. Patacca, E.; Scandone, P. Geology of the Southern Apennines. Boll. Della Soc. Geol. Ital. 2007, 7, 75-119.

35. Pescatore, T.S.; Di Nocera, S.; Matano, F.; Pinto, F. L'unita Del Fortore Nel Quadro Della Geologia Del Settore Orientale Dei Monti Del Sannio (Appennino Meridionale). Ital. J. Geosci. 2000, 119, 587-601.

36. Malinverno, A.; Ryan, W.B. Extension in the Tyrrhenian Sea and Shortening in the Apennines as Result of Arc Migration Driven by Sinking of the Lithosphere. Tectonics 1986, 5, 227-245. [CrossRef]

37. Doglioni, C. A Proposal for the Kinematic Modelling of W-Dipping Subductions-Possible Applications to the TyrrhenianApennines System. Terra Nova 1991, 3, 423-434. [CrossRef]

38. Scrocca, D.; Carminati, E.; Doglioni, C. Deep Structure of the Southern Apennines, Italy: Thin-Skinned or Thick-Skinned? Tectonics 2005, 24, 1-20. [CrossRef]

39. Pieri, P.; Gallicchio, S.; De Donato, G.; Festa, V.; Fiore, A.; Moretti, M.; Tilli, A.; Tropeano, M. Carta Geologica d'Italia. Foglio 407 San Bartolomeo in Galdo, Alla Scala 1:50,000; ISPRA: Roma, Italy, 2010.

40. Pieri, P.; Gallicchio, S.; Moretti, M.; Ciaranfi, N.; D’Alessandro, A.; Festa, V.; Maiorano, M.; Tropeano, M.; Maggiore, M.; Walsh, N. Note Illustrative Della Carta Geologica d 'Italia Alla Scala 1: 50.000, Foglio 407 San Bartolomeo in Galdo; ISPRA: Roma, Italy, 2011.

41. Di Nocera, S.; Torre, M. Geologia Dell'area Compresa Tra Deliceto e Scampitella (Appennino Foggiano). Boll. Della Soc. Geol. Ital. 1987, 106, 351-364.

42. Pescatore, T.; Di Nocera, S.; Matano, F.; Pinto, F.; Quarantiello, R.; Amore, O.; Boiano, U.; Civile, D.; Fiorillo, L.; Martino, C. Geologia Del Settore Centrale Dei Monti Del Sannio: Nuovi Dati Stratigrafici e Strutturali. Mem. Descr. Carta Geol. It. 2008, 77, 77-94.

43. Ciaranfi, N.; Loiacono, F.; Moretti, M. Note Illustrative Della Carta Geologica d'Italia Alla Scala 1: 50.000, Foglio 408 'Foggia'; ISPRA: Roma, Italy, 2011.

44. Cafaro, F.; Cotecchia, F.; Santaloia, F.; Vitone, C.; Lollino, P.; Mitaritonna, G. Landslide Hazard Assessment and Judgment of Reliability: A Geomechanical Approach. Bull. Eng. Geol. Environ. 2017, 76, 397-412. [CrossRef]

45. Hutchinson, J. General Report: Morphological and Geotechnical Parameters of Landslides in Relation to Geology and Hydrogeology. In Proceedings of the International Symposium on Landslides, Lausanne, Switzerland, 15 July 1988; pp. 3-35.

46. Hungr, O.; Leroueil, S.; Picarelli, L. The Varnes Classification of Landslide Types, an Update. Landslides 2014, 11, 167-194. [CrossRef]

47. Cotecchia, F.; Mitaritonna, G.; Elia, G.; Santaloia, F.; Lollino, P. Meccanismi Di Frana in Pendii in Argille Dell'Italia Meridionale Ed Effetti Delle Precipitazioni Meteoriche. In Proceedings of the 1st Int Workshop on Landslides: Rainfall Induced Landslide and Nowcasting Models for Early Warning System, Napoli, Italy, 8-10 June 2009; pp. 31-43.

48. Mezzina, G. Interpretazione della Pericolosità da Frana nel Centro Abitato di Motta Montecorvino (FG). Master's Thesis, Politecnico di Bari, Bari, Italy, 2007.

49. Lollino, P.; Elia, G.; Cotecchia, F.; Mitaritonna, G. Analysis of Landslide Reactivation Mechanisms in Daunia Clay Slopes by Means of Limit Equilibrium and FEM Methods. In Proceedings of the GeoFlorida 2010, Orlando, FL, USA, 20-24 February 2010; pp. 3155-3164.

50. Palmisano, F.; Elia, A. Behaviour of Masonry Buildings Subjected to Landslide-Induced Settlements. Int. J. Struct. Eng. 2014, 5, 93-114. [CrossRef]

51. Palmisano, F. Rapid Diagnosis of Crack Patterns of Masonry Buildings Subjected to Landslide-Induced Settlements by Using the Load Path Method. Int. J. Archit. Herit. 2016, 10, 438-456. [CrossRef]

52. Cotecchia, F.; Vitone, C.; Petti, R.; Soriano, I.; Santaloia, F.; Lollino, P. Slow landslides in urbanised clayey slopes: An emblematic case from the south of Italy. In Landslides and Engineered Slopes. Experience, Theory and Practice; CRC Press: Boca Raton, FL, USA, 2018; pp. 691-698.

53. BSI BS 5930: 2015 Code of Practice for Ground Investigations; British Standards Institution: London, UK, 2015.

54. Santo, A.; Senatore, M. La Successione Stratigrafica Dell'unita Dauna a Monte Sidone (Castelluccio Valmaggiore-Foggia). Mem. Della Soc. Geol. Ital. 1988, 41, 431-438.

55. Schofield, A.; Wroth, C. Critical State Soil Mechanics; McGraw-Hill: New York, NY, USA, 1968.

56. Soriano, I. Advanced Analysis of the Stress-Strain Conditions of Pianello Slope (Bovino, Italy). Master's Thesis, Politecnico di Bari, Bari, Italy, 2013. 
57. Mazzei, F. Analisi Numerica della Filtrazione in un Pendio in Frana ai Fini di Valutazioni della Stabilità. Master's Thesis, Politecnico di Bari, Bari, Italy, 2010.

58. Vezzani, L.; Festa, A.; Ghisetti, F.C. Geology and Tectonic Evolution of the Central-Southern Apennines, Italy; Geological Society of America: Boulder, CO, USA, 2010.

59. Di Lernia, A.; Cotecchia, F.; Elia, G.; Tagarelli, V.; Santaloia, F. Assessing the influence of hydraulic boundary conditions on clayey slope stability: The Fontana Monte case study. Eng. Geol. 2021, submitted. 